\title{
Climate change and Southern Ocean ecosystems I: how changes in physical habitats directly affect marine biota
}

\begin{abstract}
ANDREW J. CONSTABLE ${ }^{1,2}$, JESSICA MELBOURNE-THOMAS ${ }^{1,2}$, STUART P. CORNEY $^{2}$, KEVIN R. ARRIGO ${ }^{3}$, CHRISTOPHEBARBRAUD ${ }^{4}$, DAVID K. A. BARNES ${ }^{5}$, NATHANIEL L. BINDOFF ${ }^{2,6,7}$, PHILIP W. BOYD ${ }^{7,8}$, ANGELIKA BRANDT ${ }^{9}$, DANIEL P. COSTA ${ }^{10}$, ANDREW T. DAVIDSON ${ }^{1,2}$, HUGH W. DUCKLOW ${ }^{11}$, LOUISE EMMERSON ${ }^{1}$, MITSUO

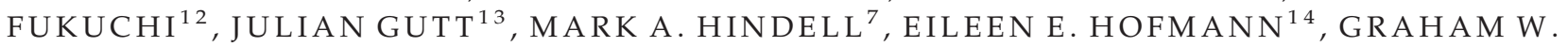
HOSIE $^{1,2}$, TAKAHIRO IIDA ${ }^{12}$, SARAH JACOB ${ }^{1}$, NADINE M. JOHNSTON ${ }^{5}$, SO KAWAGUCHI ${ }^{1,2}$, NOBUO KOKUBUN ${ }^{12}$, PHILIPPE KOUBBI ${ }^{15}$, MARY-ANNE LEA ${ }^{7}$, AZWIANEWI MAKHADO ${ }^{16}$, ROB A. MASSOM ${ }^{1,2}$, KLAUS MEINERS ${ }^{1,2}$, MICHAEL P. MEREDITH ${ }^{5}$, EUGENE J. MURPHY ${ }^{5}$, STEPHEN NICOL ${ }^{2,7}$, KEITH REID $^{17}$, KATE RICHERSON $^{10}$, MARTIN J. RIDDLE $^{1}$, STEPHEN R. RINTOUL ${ }^{2,6}$,WALKER O. SMITH JR ${ }^{18}$, COLIN SOUTHWELL ${ }^{1,2}$, JONATHON S. STARK ${ }^{1}$, MICHAEL SUMNER ${ }^{1}$, KERRIEM. SWADLING ${ }^{7}$, KUNIO T. TAKAHASHI $^{12}$, PHIL N. TRATHAN ${ }^{5}$, DIRK C. WELSFORD ${ }^{1}$, HENRI WEIMERSKIRCH ${ }^{4}$, KAREN J. WESTWOOD ${ }^{1,2}$, BARBARA C. WIENECKE ${ }^{1}$, DIETER WOLFGLADROW $^{13}$, SIMON W. WRIGHT ${ }^{1,2}$, JOSE C. XAVIER ${ }^{5,19}$ and PHILIPPE ZIEGLER ${ }^{1}$

${ }^{1}$ Australian Antarctic Division, Channel Highway, Kingston, Tasmania 7050, Australia, ${ }^{2}$ Antarctic Climate and Ecosystems Cooperative Research Centre, Private Bag 80, Hobart, Tasmania 7001, Australia, ${ }^{3}$ Department of Environmental Earth System Science, Stanford University, Stanford, CA, USA, ${ }^{4}$ Centre d'Etudes Biologiques de Chizé, UMR 7372 CNRS/Univ La Rochelle, Villiers en Bois 79360, France, ${ }^{5}$ British Antarctic Survey, High Cross, Madingley Rd, Cambridge CB3 OET, United Kingdom, ${ }^{6}$ CSIRO Marine and Atmospheric Research, Hobart Tasmania 7001, Australia, ${ }^{7}$ Institute for Marine and Antarctic Studies, University of Tasmania, Private Bag 129, Hobart Tasmania 7001, Australia, ${ }^{8}$ Department of Chemistry, Centre for Chemical and Physical Oceanography, University of Otago, Dunedin, New Zealand, ${ }^{9}$ Biocenter Grindel and Zoological Museum, University of Hamburg, Martin-Luther-King-Platz 3, Hamburg 20146, Germany, ${ }^{10}$ Ecology \& Evolutionary Biology, University of California, Santa Cruz, CA, USA, ${ }^{11}$ Lamont-Doherty Earth Observatory, Columbia University, Palisades, NY 10964, USA, ${ }^{12}$ National Institute of Polar Research, 10-3 Midori-cho, Tachikawa-shi Tokyo 190-8518, Japan, ${ }^{13}$ Alfred-Wegener-Institut HelmholtzZentrum für Polar- und Meeresforschung, Bremerhaven, Germany, ${ }^{14}$ Center for Coastal Physical Oceanography, Old Dominion University, Norfolk, VA, USA, ${ }^{15}$ UMR 7208 BOREA, Sorbonne Universités, UPMC University Paris 06, MNHN, CNRS, IRD, UCBN, 57 rue Cuvier CP 26, Paris 75005, France, ${ }^{16}$ Department of Environment Affairs, Oceans and Coasts, P.O Box 52126, Cape Town 8000, South Africa, ${ }^{17}$ Commission for the Conservation of Antarctic Marine Living Resources, 181 Macquarie St, Hobart, Tasmania 7000, Australia, ${ }^{18}$ Virginia Institute of Marine Science, College of William \& Mary, Gloucester Pt. VA, USA, ${ }^{19}$ Institute of Marine Research, University of Coimbra, Coimbra 3001-401, Portugal
\end{abstract}

\begin{abstract}
Antarctic and Southern Ocean (ASO) marine ecosystems have been changing for at least the last 30 years, including in response to increasing ocean temperatures and changes in the extent and seasonality of sea ice; the magnitude and direction of these changes differ between regions around Antarctica that could see populations of the same species changing differently in different regions. This article reviews current and expected changes in ASO physical habitats in response to climate change. It then reviews how these changes may impact the autecology of marine biota of this polar region: microbes, zooplankton, salps, Antarctic krill, fish, cephalopods, marine mammals, seabirds, and benthos. The general prognosis for ASO marine habitats is for an overall warming and freshening, strengthening of westerly winds, with a potential pole-ward movement of those winds and the frontal systems, and an increase in ocean eddy activity. Many habitat parameters will have regionally specific changes, particularly relating to sea ice characteristics and seasonal dynamics. Lower trophic levels are expected to move south as the ocean conditions in which they are currently found move pole-ward. For Antarctic krill and finfish, the latitudinal breadth of their range will depend on their tolerance of warming oceans and changes to productivity. Ocean acidification is a concern not only for calcifying organisms but also for crustaceans such as Antarctic krill; it is also likely to be the most important change in benthic habitats over the coming century. For marine mammals and birds, the expected changes primarily relate to
\end{abstract}


their flexibility in moving to alternative locations for food and the energetic cost of longer or more complex foraging trips for those that are bound to breeding colonies. Few species are sufficiently well studied to make comprehensive species-specific vulnerability assessments possible. Priorities for future work are discussed.

Keywords: Antarctica, benthos, climate change, krill, marine ecosystems, marine mammals, ocean acidification, penguins, plankton, sea ice

Received 15 December 2013 and accepted 5 March 2014

\section{Introduction}

Antarctic and Southern Ocean marine ecosystems have been changing for at least the last 30 years (Turner et al., 2009a, 2013). The most obvious physical changes to date include increasing ocean temperatures, poleward shift of ocean fronts and regionally contrasting changes in the extent and seasonality of sea ice (Böning et al., 2008; Bracegirdle et al., 2008; Sokolov \& Rintoul, 2009; Turner et al., 2009a, 2013; Stammerjohn et al., 2012). These changes have had, and will continue to have profound implications for marine ecosystems around Antarctica and in the Southern Ocean, although the effects may be regionally specific (Smetacek \& Nicol, 2005; Boyd et al., 2008; Nicol et al., 2008; Massom \& Stammerjohn, 2010). We, hereafter, refer to these marine ecosystems collectively using the acronym ASO to connote the combined marine areas of the circumpolar Antarctic continental shelf and the Southern Ocean.

The Southern Ocean, defined here as waters south of the Subtropical Front, is of major importance in the Earth System (Turner et al., 2009a). The ecosystem dynamics of the region are dominated by the Antarctic Circumpolar Current (ACC) and its frontal systems, polar seasonality, and the annual advance and retreat of sea ice (Constable et al., 2003; Grant et al., 2006; Constable \& Doust, 2009; Massom \& Stammerjohn, 2010). The Southern Ocean is characterized as a High Nutrient, Low Chlorophyll (HNLC) system because of the limitation of phytoplankton growth by micronutrients across much of the open ocean (Strzepek et al., 2011; Boyd et al., 2012). The highest primary production occurs in conjunction with shallow waters, linked to the supply of iron (Smetacek \& Nicol, 2005).

Reviews have previously been undertaken on the structure, function and change of the Southern Ocean ecosystem at sector and regional scales (Ducklow et al., 2012a; Murphy et al., 2012a,b, 2013; Nicol \& Raymond, 2012; Smith et al., 2012); we endeavour to uniformly apply terminology on different spatial scales where 'sector' is defined in the text and corresponds approximately to an ocean basin (Atlantic, Indian, West Pacific, East Pacific), 'region' applies to a scale akin to, for example, the Weddell and Ross Seas, west Antarctic Peninsula, East Antarctica, Kerguelen Plateau; and 'area' is more of a local scale such as an ice shelf or island. Some circumpolar syntheses of the ecology of particular habitat types and the consequences of change are also available (e.g. sea-ice habitats - Massom \& Stammerjohn, 2010; general - Turner et al., 2009a). In addition, a comprehensive assessment of the biogeography of ASO biota is currently underway (De Broyer \& Koubbi, 2014) but will not include assessments of climate change impacts. A clear gap in these reviews is a close examination of how specific changes in physical habitats may impact directly on the ecology of species at different trophic levels (Fig. 1), thereby giving rise to indirect impacts on one or both of bottom-up (production) and/or top-down (predation) forcings in the ecosystem (Fig. 2). Here, we update this body of literature to (i) summarize the changes in marine habitats due to climate change; (ii) consider the general mechanisms of how taxa may be directly impacted by these changes; and (iii) compare and contrast the ecosystem changes in the different sectors of the ASO as a result of those impacts on biota i.e. the ecosystem impacts of climate variability and change. Importantly, this synthesis will provide a comparative framework for assessing the likelihood of future climate change impacts.

This synthesis is comprized of two papers. This article undertakes the first two parts of the assessment habitats and direct effects on biota. The latter is based on the known regional changes the biota have experienced and knowledge of the drivers of those changes. In the second (companion) article, we examine more closely the observed and expected responses of ecosystems to climate change in the different ASO sectors and consider how these systems may respond in future, particularly with respect to their resilience and the potential for alternative stable regimes to arise.

Insufficient data are currently available to make comprehensive species-specific vulnerability assessments (including the concepts of exposure, sensitivity, potential for impact, and adaptive capacity) similar to that of Daw et al. (2009) for commercially harvested species and of Hollowed et al. (2013) for Arctic species. Nevertheless, there is sufficient knowledge to identify key interactions for many of the groups. Firstly, we describe the general attributes of the pelagic and benthic habitats of the Southern Ocean and how they have changed in recent decades - the exposure component of a vulnerability assessment. We then synthesize knowledge of, and 

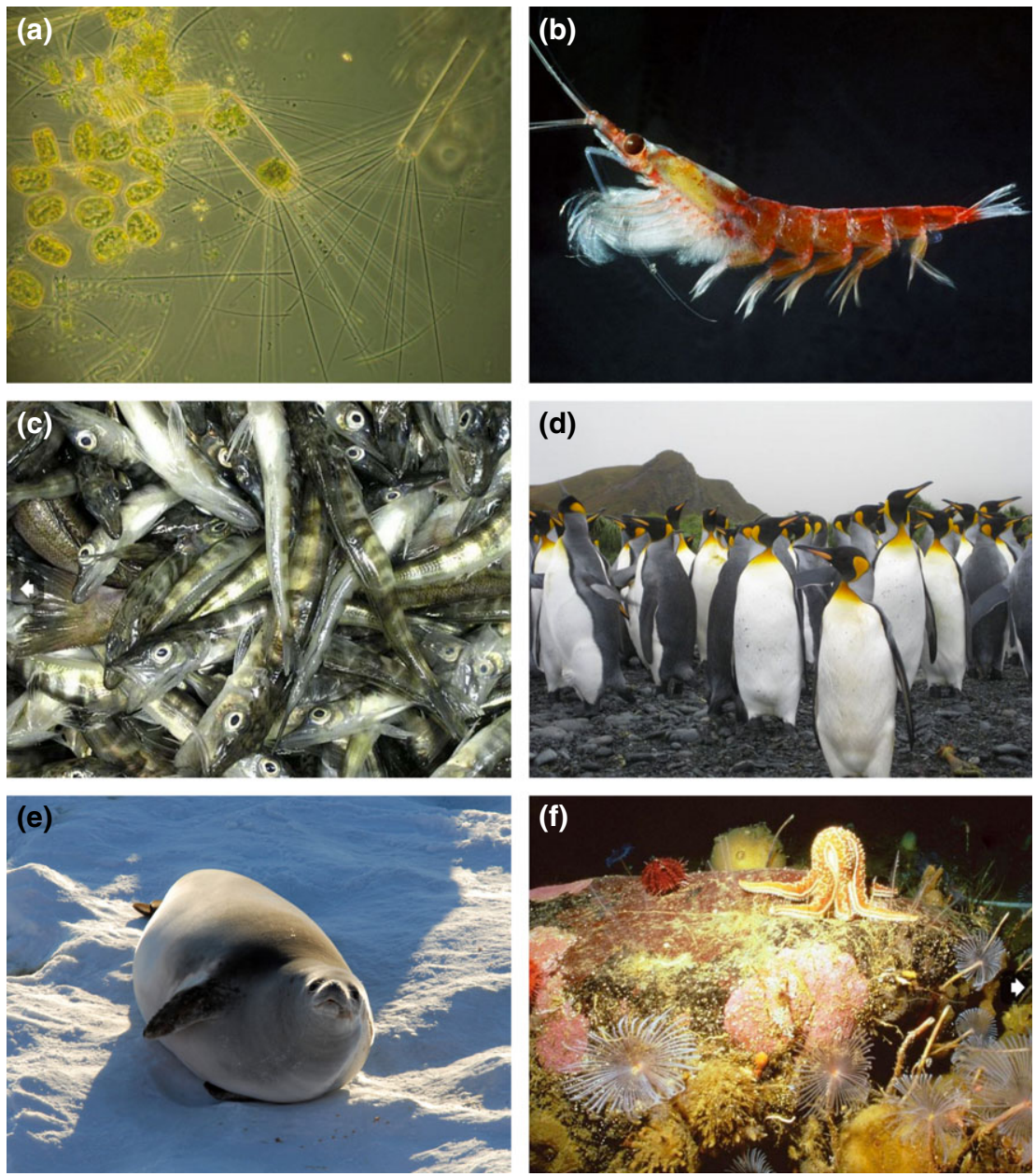

Fig. 1 A broad range of Antarctic marine taxa are responding to climate change impacts in Southern Ocean habitats, for example: (a) phytoplankton communities (photo: ACE CRC), (b) Antarctic krill (photo: S. Brookes), (c) mackerel icefish (photo: AFMA), (d) king penguins (photo: Clint D), (e) crabeater seals (photo: D. Costa), and (f) benthic species (photo: A. Tabor).

provide some current views on, the role of changing habitats in driving changes in the following groups microbes, zooplankton and salps, Antarctic krill (Euphausia superba), fish and cephalopods, marine mammals and seabirds, and benthos. This article concludes by summarizing the primary changes expected for different biota and the gaps needing to be filled to describe more fully the autecological response of ASO biota to climate change impacts.

\section{Exposure: observed and predicted change in physical habitats}

Habitats in the Southern Ocean are structured by oceanic and topographic features. From south to north, the Antarctic continental shelf, the seasonally variable seaice zone (comprising both stationary fast ice and moving pack ice) and oceanic fronts approximately delimit zonal biogeographic regions with distinct physical, chemical, and biological characteristics (Fig. 3). The major circulation features of the Southern Ocean are strongly steered by bathymetry, and the large Ross and Weddell gyres tend to isolate much of the Antarctic coastal region from the relatively warm waters of the ACC. Zonal homogeneity is broken by features such as these gyres, the Antarctic Peninsula, the Scotia Arc in the southwest Atlantic, the Kerguelen Plateau in the Indian sector, and the Macquarie Ridge and seamounts to the northwest of the Ross Sea in the western Pacific sector (Grant et al., 2006; Kaiser et al., 2009). These topographic features create four natural sectors of the Southern Ocean - the Atlantic, Indian, West Pacific and East Pacific sectors (Fig. 3).

The highly seasonal and variable physical properties are major drivers of the dynamics of Southern Ocean ecosystems: winter reductions in irradiance 


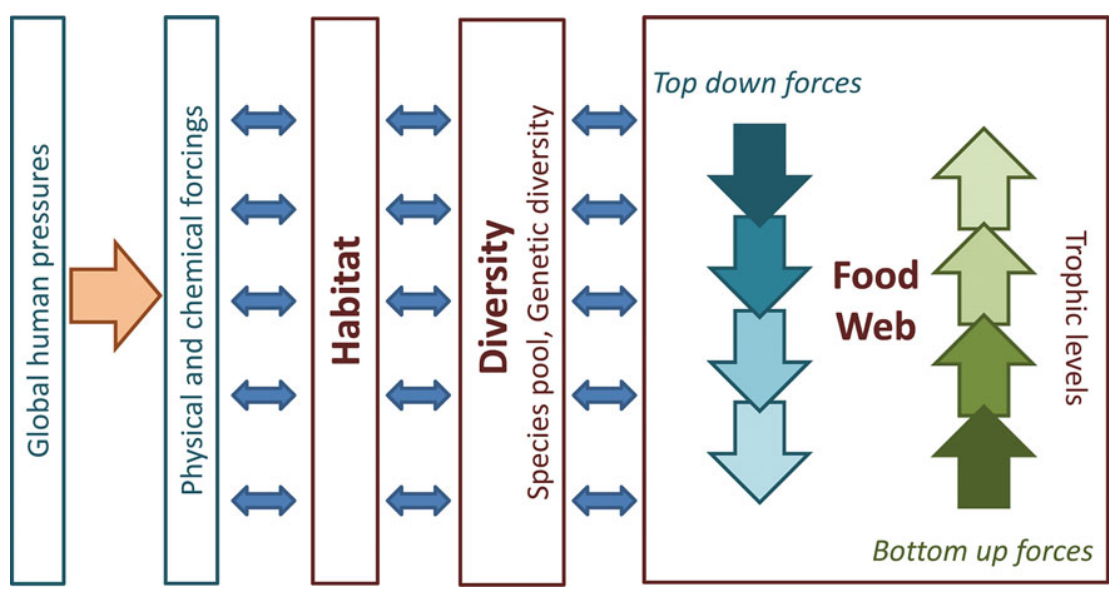

Fig. 2 Schematic illustrating how changes in the physical environment affect habitats, species diversity, and then food webs. The large horizontal arrow shows the effects of global human pressures in the system. The food web can be considered as a number of trophic levels, which may be impacted by bottom-up and/or top-down forces in the food web. Small double-headed horizontal arrows indicate the connections between components, including potential feedbacks. The number of those horizontal arrows indicates that changes in habitats, diversity, and food webs may occur at any trophic level, potentially giving rise to both bottom-up and top-down effects.

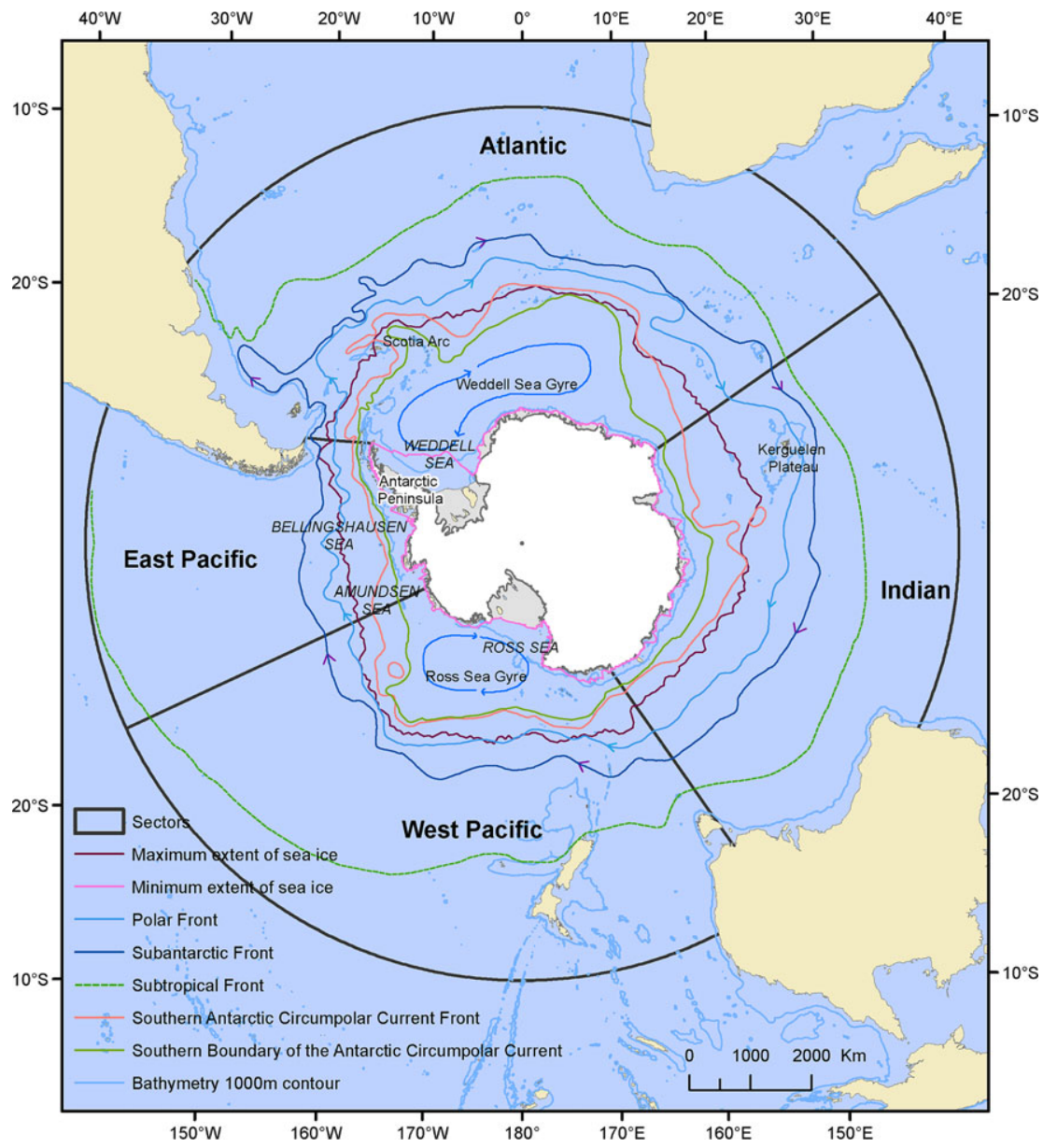

Fig. 3 Major physical features of the Southern Ocean, including key locations referred to in the text, major sectors differentiating the ecosystems, minimum and maximum extent of sea ice, the Subtropical, Subantarctic and Polar Fronts, Southern Boundary of the Antarctic Circumpolar Current, and the $1000 \mathrm{~m}$ countour. (Color in the online version) 
and water temperature, and winter increases in mixed layer depth, nutrients, and sea-ice extent (Figs 4 and 5). These habitat variables combine, for example, to control the availability of light and nutrients for primary producers and to influence access to food and breeding habitat for species dependent on sea ice. The magnitude and interaction of these seasonal factors varies between different regions of the Southern Ocean, giving rise to substantial regional variation in the distribution of habitats (Grant et al., 2006) (Fig. 6).

The El Niño/Southern Oscillation (ENSO) is one of the dominant modes of climate variability that influ- ences the ASO on subdecadal time scales and is triggered from the tropics (Kwok \& Comiso, 2002). The Southern Annular Mode (SAM) is the dominant mode of extratropical variability in the Southern Hemisphere (sen Gupta et al., 2012). It operates on timescales from weeks to decades, including interannual periods, and is particularly pronounced in the magnitude and position of the zonal winds. On decadal to multidecadal timescales, significant modes of variability include the Pacific Decadal Oscillation and the Atlantic Multi-decadal Oscillation (sen Gupta et al., 2012) which may, in turn, cause variability in physical habitats in the ASO.

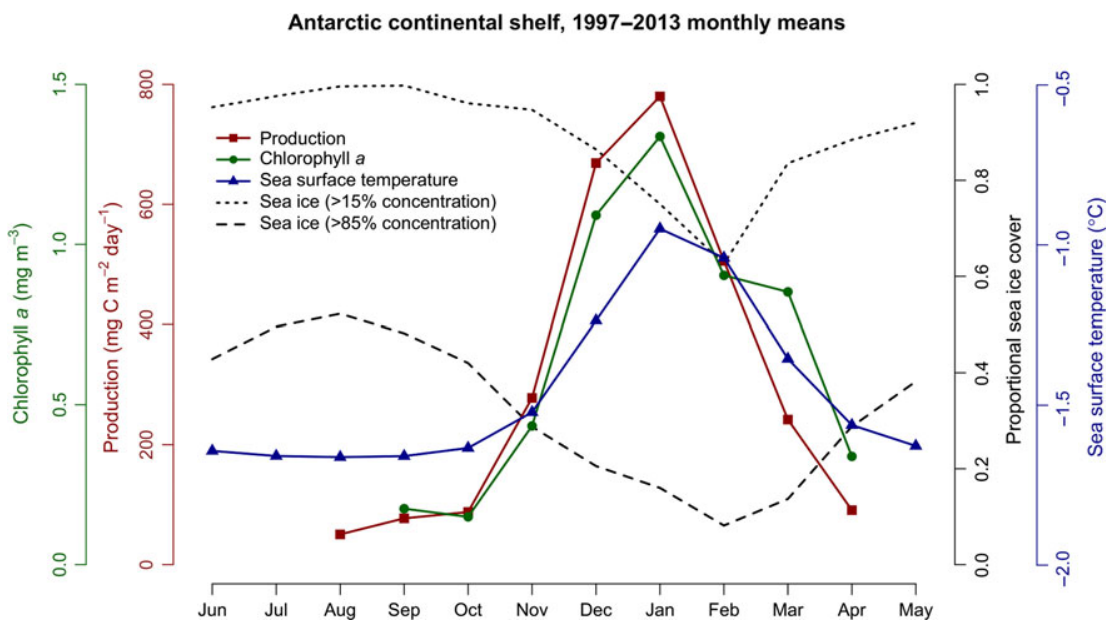

Fig. 4 Mean annual cycles for production, chlorophyll $a$, sea surface temperature (SST) and sea ice over the Antarctic continental shelf (modified from O'Brien et al., 2009). Production and chlorophyll $a$ are from Arrigo et al. (2008) and Feldman \& McClain (2013), respectively. SST is derived from the NOAA Optimum Interpolation 1/4 Degree Daily Sea Surface Temperature Analysis (Reynolds et al., 2007). The seasonal cycle for sea ice is represented as the proportion of this region covered by ice of at least 15\% (small dashed line) and at least 85\% (large dashed line) concentration. Sea-ice concentration data are the NASA Bootstrap SMMR-SSM/I combined dataset from the US National Snow and Ice Data Centre \{http://nsidc.org; Comiso, 1999\}. Monthly means are for time series from 1997 to 2013, apart from chlorophyll $a$ which is 2003-2013. (Color in the online version)
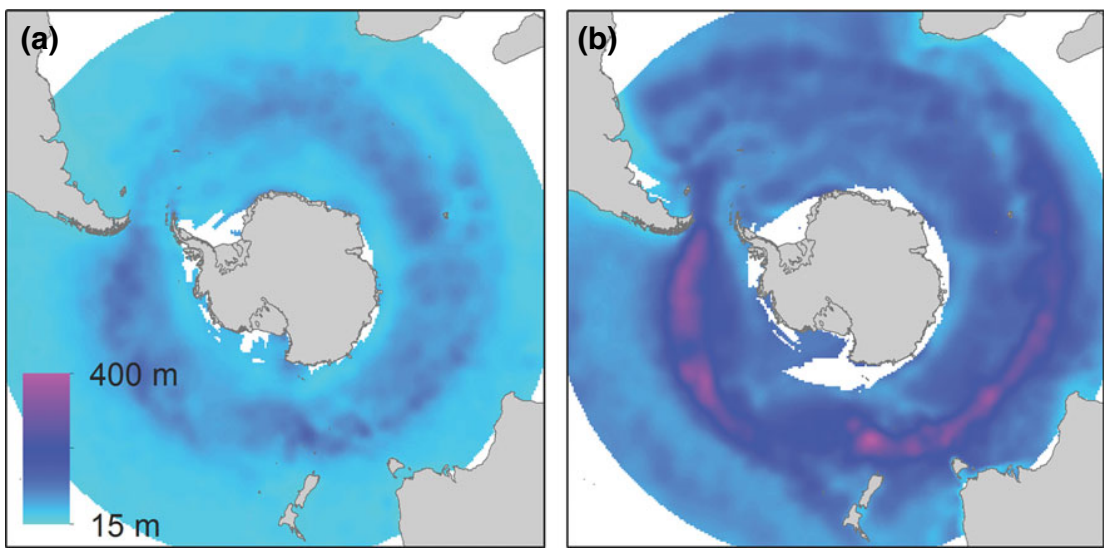

Fig. 5 Mean summer (a) and winter (b) mixed layer depth for the Southern Ocean (from Sallée et al., 2010). Summer months are November-April, winter months are May-October. (Color in the online version) 


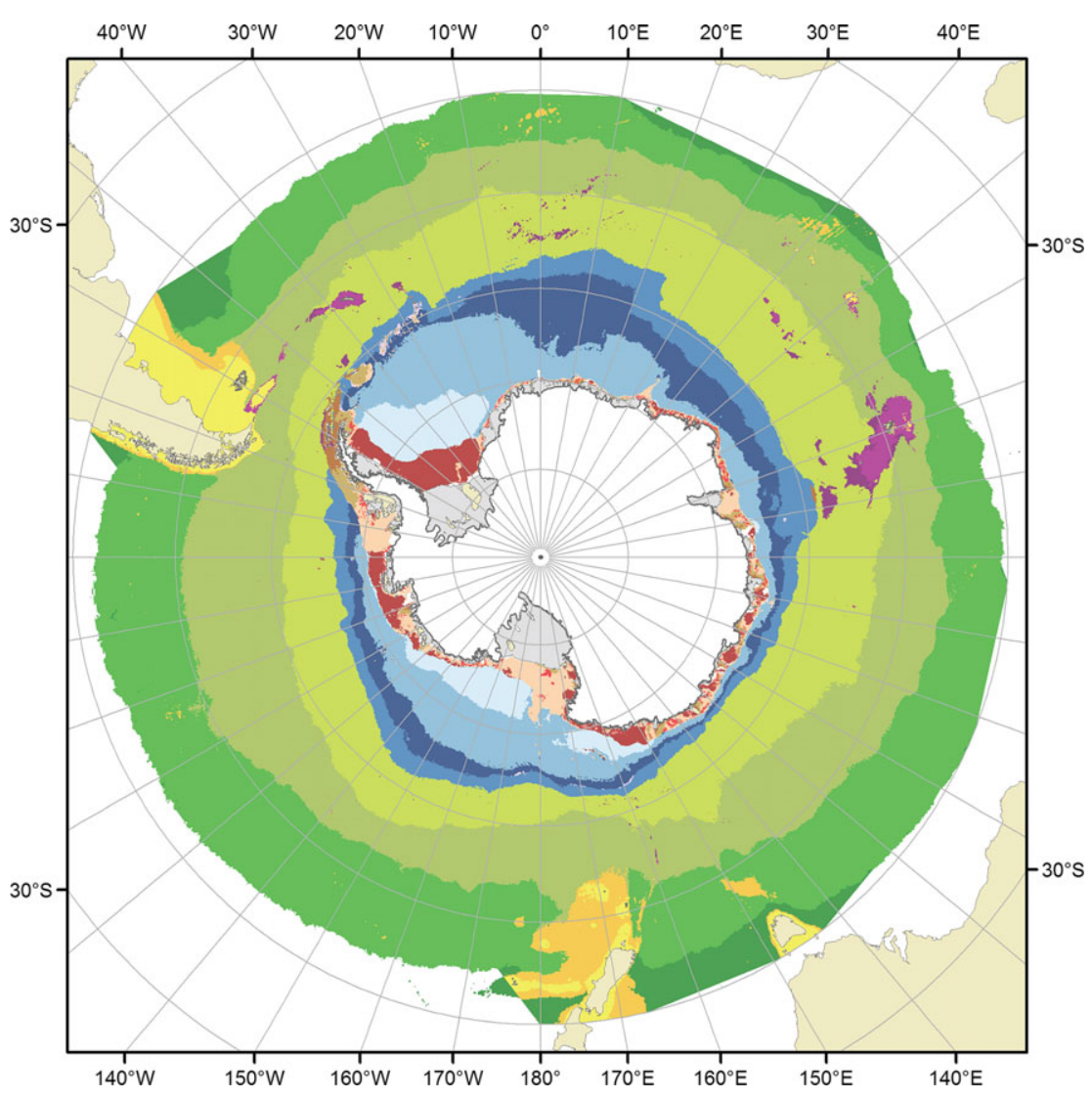

Fig. 6 Pelagic regionalization for the Southern Ocean (B. Raymond, Australian Antarctic Division, 2011, updated from Grant et al., 2006). Twenty cluster types are derived from sea surface temperature, depth and sea ice cover data layers. Methods for regionalization follow those of Grant et al. (2006). (Color in the online version)

Observed changes in ocean habitats include deepreaching warming (Böning et al., 2008; Gille, 2008) and freshening due to increased precipitation and glacial discharge (Böning et al., 2008; Durack \& Wijffels, 2010; Hellmer et al., 2010; Helm et al., 2010; Jacobs \& Giulivi, 2010). A southward shift of the fronts of the ACC, estimated using sea surface height, has been suggested as a mechanism to explain at least some of the observed Southern Ocean warming (Gille, 2008; Sokolov \& Rintoul, 2009; Sura \& Gille, 2010). Changes in surface fluxes of heat and freshwater may also have played a role in the warming (Meijers et al., 2011b).

Many observed changes in physical habitats have likely been driven by the pole-ward shift and strengthening of the westerly winds (SAM becoming positive in recent decades; for relative roles of greenhouse gas forcing and ozone hole in these changes see Cai et al., 2005; and Thompson et al., 2011). For example, stronger wind forcing in the Southern Ocean has been linked to an increase in eddy kinetic energy (Meredith \& Hogg, 2006) and pole-ward eddy heat flux (Hogg et al., 2008), the latter of which could also contribute to warming.
Bathymetry, fronts, and eddies are important for bringing nutrient-rich deep water to the surface. Most regions of elevated chlorophyll in the ASO are related to regions of upwelling of nutrients due to the interaction of the ACC with topography (Sokolov \& Rintoul, 2007). Eddies are increasingly thought to be a major driver of Southern Ocean systems (Meredith \& Hogg, 2006), not only for their control on primary and secondary production but also because they may be features used by marine mammals and seabirds to assist with foraging (Sokolov et al., 2006).

The oceanic mixed layer depth (MLD) is a major controller of primary production: deeper mixed layers bring more nutrients to the surface but result in phytoplankton spending less time in shallower water where photosynthetically active radiation (PAR) is highest. Wind and air-sea heat exchange cause these depths to vary throughout the Southern Ocean; different regions may have a consistently deep or shallow mixed layer, even though they are at the same latitude (Dong et al., 2008; Sallée et al., 2010; Meijers et al., 2011a) (Fig. 5). Further, responses of the surface MLD to monthly 
variations in the SAM has been shown unexpectedly to vary asymmetrically between regions (Sallée et al., 2010).

The coastal systems around Antarctica comprise deep shelf areas ( $\sim 500 \mathrm{~m}$ depth) broken by canyons and cross-shelf depressions (Grant et al., 2006) (Fig. 7). Banks of $\sim 500 \mathrm{~m}$ depth or less are scoured by icebergs (Dowdeswell \& Bamber, 2007). Recurrent coastal polynyas, areas of open water within pack ice, are prevalent in the lee of coastal promontories and grounded icebergs and where katabatic winds cascade seawards from the continental ice sheet (Barber \& Massom, 2007). These areas are highly productive (Arrigo \& Van Dijken, 2003) and some are important for the formation of Antarctic Bottom Water (Rintoul, 1998): dense water that spills down the continental slope and spreads northward (Meredith et al., 2011), in turn influencing the benthos with its water chemistry and organic particulates.

Sea ice is critically important to the ASO ecosystem. It structures the habitat, serves as a resting and breeding platform, provides food resources and refugia, serves as a seasonal nutrient storage before releasing those nutrients during melt, and affects reproductive cycles, recruitment, and foraging behaviour for a wide range of species (Massom \& Stammerjohn, 2010; Thomas \& Dieckmann, 2010). The interannual variability in sea-ice extent and changes in the timing and duration of the sea-ice season can be important drivers of the

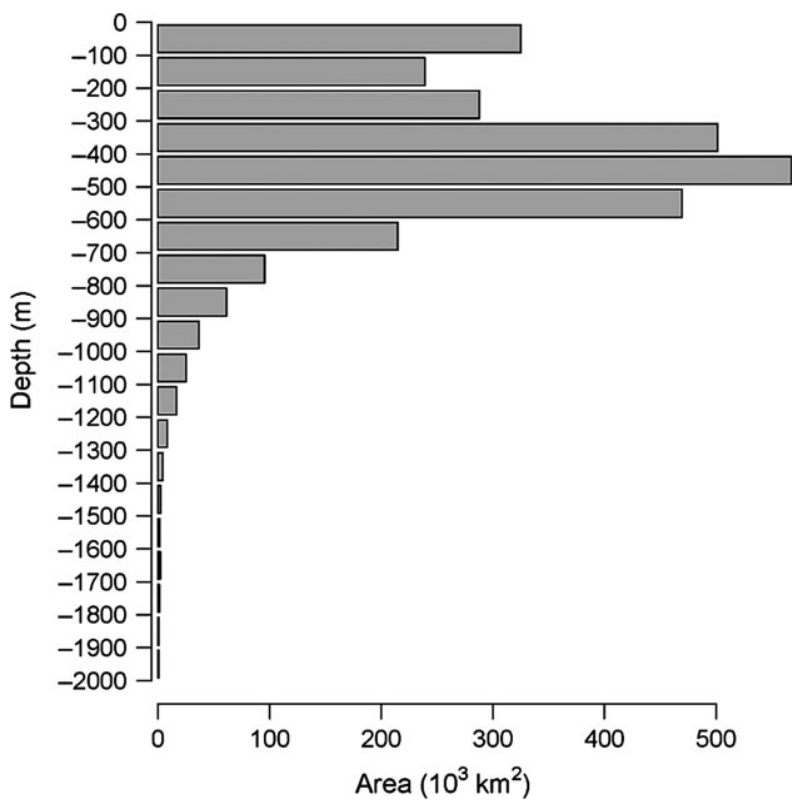

Fig. 7 Total area between $100 \mathrm{~m}$ depth contours in the regions around Antarctica less than $2000 \mathrm{~m}$ deep (modified from O'Brien et al., 2009). interannual variability in the ecosystem as a whole (Massom \& Stammerjohn, 2010; Murphy et al., 2012a). In contrast to the Arctic, the overall extent of Antarctic sea ice has increased slightly since satellite observations first became available in 1979. Indirect evidence from methanesulphonic acid measurements in ice-sheet cores (Curran et al., 2003; Abram et al., 2013) and from historical whaling records (de la Mare, 1997, 2009) indicate a decline in sea ice between the 1950s and 1970s (but see Ackley et al., 2003).

Compared to the recent overall trend, much stronger and sometimes contrasting regional changes have occurred; sea-ice extent has increased by $4.5-5 \%$ per decade in the Ross Sea and decreased by $5-6 \%$ per decade to the west of the Antarctic Peninsula during the satellite era (Comiso et al., 2011; Stammerjohn et al., 2012). Over the same period, the seasonal duration of sea ice has shortened on the west side of the Antarctic Peninsula by $3.1 \pm 1.0$ days $\mathrm{yr}^{-1}$, which is comparable to the greatest rate of sea-ice loss observed in the Arctic (Stammerjohn et al., 2012). In contrast, the duration in the western part of the Ross Sea has increased by $2.4 \pm 0.4$ days $\mathrm{yr}^{-1}$. These changes in the regional distribution of sea ice have been linked to changes in wind patterns, including a pole-ward shift and strengthening of the westerlies and an increase in strength of the Amundsen Sea low pressure system (Turner et al., $2009 b, c, 2013)$. Other factors may include changes in sea-ice advection from source areas and thermodynamic processes (Holland \& Kwok, 2012), and increased glacial melt causing stabilized upper layers conducive to sea-ice formation and persistence (Bintanja et al., 2013). By comparison, change in patterns of sea-ice seasonality in East Antarctica is more complex (Massom et al., 2013).

Changes in sea ice will affect benthic habitats, particularly in shallow coastal areas, through changes in light conditions (Clark et al., 2013). Further, increases in surface production due to thinning ice could lead to increases in allochthonous nutrient inputs to the benthos. These habitats may also be affected by abrupt loss of ice shelves such as has happened on the Antarctic Peninsula (Cook et al., 2005; Cook \& Vaughan, 2010). As well, freshening and changes in chemistry of Antarctic Bottom Water (Rintoul, 2007) may be important to these habitats in future.

The breakup of ice shelves can expose benthic and pelagic areas to more light, with ensuing increases in primary production (Peck et al., 2010). Icebergs resulting from this breakup will increase bottom scour in shallow areas (Barnes \& Souster, 2011; Gutt et al., 2011). Meltwater from icebergs may release reservoirs of iron and other nutrients stored in the continental ice from dust deposited over millennia, which in turn will 
increase primary productivity (Boyd et al., 2012). Moreover, further ice shelf disintegration may happen if rates of warming experienced in the Antarctic Peninsula area occur in other regions (Scambos et al., 2003).

In addition to climate change processes, $\mathrm{CO}_{2}$ enrichment and absorption by the Southern Ocean is causing a shift towards more acidic conditions (Midorikawa et al., 2012). As $\mathrm{CO}_{2}$ is more soluble in cold polar waters than in temperate waters, the cold polar waters will become corrosive to calcium carbonate earlier than warmer waters at lower latitudes (McNeil \& Matear, 2008; Moy et al., 2009). Decreased concentration of carbonate ions in the Southern Ocean will potentially impact the physiology of organisms, as well as carbonate deposition by calcifying organisms (Moy et al., 2009; Byrne, 2011; Kawaguchi et al., 2011, 2013; Roberts et al., 2011a; Ingels et al., 2012; Bednaršek et al., 2012a).

Projections of future conditions using coupled oceanatmosphere models are confirming past findings for the Southern Ocean (e.g. Russell et al., 2006) of continuing southward movement of fronts, warming and freshening of surface waters, and increased stratification (sen Gupta et al., 2009; Meijers et al., 2012; Bracegirdle et al., 2013; Sallée et al., 2013a,b). These changes are expected to arise from an intensification of winds (positive SAM) and a southward expansion of the subtropical gyres (Meijers et al., 2012). They are also likely to increase upwelling of warm, salty, nutrient-rich water, and potentially lead to more incursions of warm Circumpolar Deep Water on to the Antarctic continental shelf (e.g. see sen Gupta et al., 2009). However, there is a need for increased investigation into the mechanisms by which this is achieved and the impacts of such incursions on the ice shelves (e.g. Dinniman et al., 2012).

Projections from climate change modelling experiments point to an altered upper ocean, with both increased density stratification (surface warming and increased precipitation) and shallower surface mixed layers. Enhanced stratification will reduce the supply of nutrients from the deep ocean (Boyd et al., 2008), whereas a shallower mixed layer will increase mean irradiance levels. Model projections of the joint outcome of these changes to the upper ocean (by 2100) reveal that the rate of net primary production will increase in subantarctic waters, and south of the ACC, and mainly decrease in the polar waters between these regions (Arrigo et al., 2008; Bopp et al., 2013). Although nutrient fluxes are also affected by large-scale upwelling of Circumpolar Deep Water at the Antarctic Divergence (driven by wind-induced Ekman transport), predictions for changes in upwelling are equivocal. Wind strengths are expected to increase, but much of the expected increase in Ekman transport may be mitigated by an increase in pole-ward eddy transport (Lovenduski \& Gruber, 2005; Hogg et al., 2008). Models and scaling arguments suggest that stronger winds will likely cause stronger upwelling, but that the magnitude of the response is less than expected due to the wind alone because of partial compensation by eddy fluxes (Farneti \& Delworth, 2010; Meredith et al., 2012; Morrison \& Hogg, 2012).

Sea ice is expected to decrease in extent (Bracegirdle et al., 2008), volume (Arzel et al., 2006) and annual duration (i.e. lengthen the open water season) (Stammerjohn et al., 2012). However, the prognosis for sea ice remains one of the greatest uncertainties surrounding ASO habitats in the model projections as there is still some discrepancy between observations and model simulations of Antarctic sea-ice extent; observations show a small increase in sea-ice extent in recent decades while climate models show a decline over the same period (Maksym et al., 2012; Turner et al., 2012).

\section{Vulnerability: effects on biota}

\section{Marine microbes}

In the ASO, primary productivity is strongly mediated by micronutrient availability (especially iron), temperature, carbonate chemistry and light, due to deep vertical mixing and extreme seasonal fluctuations in irradiance and sea-ice cover (Boyd et al., 2008, 2012; Smith \& Comiso, 2008; Melbourne-Thomas et al., 2013). Iron limitation in much of the open Southern Ocean has resulted in low standing stocks of phytoplankton (Strzepek et al., 2011; Boyd et al., 2012). Large phytoplankton (large diatoms $>20 \mu \mathrm{m}$ and, in some areas, colonial Phaeocystis antarctica up to $6 \mathrm{~mm}$ long) are the dominant primary producers (Arrigo et al., 1999), particularly in the coastal waters that contribute most to annual carbon export fluxes. Although infrequently dominant, small phytoplankton (flagellates and unicellular Phaeocystis antarctica $5-10 \mu \mathrm{m}$ and small diatoms $<20 \mu \mathrm{m}$ ) represent another energy pathway.

Marine microbes mediate global climate through photosynthetic carbon fixation from atmospheric $\mathrm{CO}_{2}$. Some phytoplankton also influence cloudiness and atmospheric albedo over the Southern Ocean, thereby altering the global heat balance. Increased cloudiness and albedo occurs through the release of volatile plankton metabolites, such as dimethyl sulphide (Charlson et al., 1987; Kasamatsu et al., 2004a,b; Krüger \& Graßl, 2011) and isoprenes (Meskhidze \& Nenes, 2006), or nonvolatile organics in bubbles (Quinn \& Bates, 2011).

Functional assemblages of phytoplankton are predictably associated with physical and ecological features and processes (temperature, ice retreat, mixed 
layer depth, iron availability, bloom development, grazing, and senescence), but little is known about whether the geographical distributions of these functional groups have changed in the Southern Ocean. Small flagellates dominate the low-nutrient regions of the pelagic Southern Ocean, while diatoms are most abundant in the more nutrient-rich Polar Front region and on the continental shelves, along with the haptophyte Phaeocystis antarctica. However, warming of the ocean may favour southwards range extensions by certain groups, as has been observed for the coccolithophorid, Emiliania huxleyi (Cubillos et al., 2007), and the heterotrophic dinoflagellate Noctiluca scintillans (McLeod et al., 2012). N. scintillans was observed $240 \mathrm{~km}$ south of Tasmania in the subantarctic zone in December 2010 (McLeod et al., 2012), and can be linked to the intensification of the East Australian Current, which is likely to continue to strengthen and transport warm water and resident phytoplankton further south (Cai et al., 2005).

Rates of growth, metabolism and activity of auto(phytoplankton) and heterotrophs (bacteria and microzooplankton) and viruses may be enhanced by warming (Rose \& Caron, 2007; Danovaro et al., 2011). However, the overall response of a taxon will be a combination of its physiological response to increased temperature coupled with any nutrient and light limitation, and the tolerances of that taxon to environmental change (Rose \& Caron, 2007; Boyd et al., 2008; Feng et al., 2009). For example, there is no consistent effect of increased temperature on bacterial growth rates in polar seas (Kirchman et al., 2009). Heterotrophic bacterial assemblages in the western Antarctic Peninsula shelf region responded positively in density to warmer temperatures in some years and negatively in others (Ducklow et al., 2012b). It is therefore difficult to predict changes in the relative abundance and activity of microbial taxa with warming (Marchant et al., 2001).

Ice-associated primary production in the ASO, comprising ice algal production and pelagic production at retreating sea-ice edges, is expected to decline with predicted decreases in sea-ice extent (Arrigo \& Thomas, 2004; Arrigo et al., 2008; Vancoppenolle et al., 2013). Algae are found living on the bottom, and in the interior and surface layers of sea ice. Their annual growth cycle is influenced by availability of suitable habitat and seasonal variations in PAR. At the population (local) scale growth is modulated by the in situ light regime, which in turn is negatively impacted by increasing ice and snow thickness, and nutrient availability, which is dependent on sea-ice permeability (Golden et al., 1998; Tison et al., 2008; Raymond et al., 2009; Arrigo et al., 2010, 2012; Taylor et al., 2013). Large-scale assessments of the effects of changing sea-ice conditions on ice algal production remain difficult because observations are sparse and accurate models are not well developed in capturing the complexity of physical and biogeochemical processes or algal productivity in sea ice (Vancoppenolle et al., 2013). A recent analysis of a large circum-Antarctic observational dataset showed that the vertical distribution of ice algae is dependent on ice thickness, and suggests that predicted changes in sea-ice thickness (e.g. Arzel et al., 2006) may impact on the availability of ice algae as food for pelagic herbivores (Meiners et al., 2012).

Increased pelagic primary production at sea-ice edges (marginal ice zone) occurs during the spring and summer sea-ice retreat. Production of melt water and reduced wind-mixing (due to partial sea-ice cover) act to increase ocean surface layer stratification, which may result in extensive phytoplankton blooms (Smith \& Nelson, 1985). Sea ice may also release nutrients, in particular the micronutrient iron (Lannuzel et al., 2007), and may seed the water column with ice algae (Lizotte, 2001). Other than the physical properties of the sea ice, the rate of sea-ice retreat and wind speed are considered important drivers of ice-edge blooms (Constable et al., 2003; Fitch \& Moore, 2007).

Changes in marginal ice zone dynamics due to changes in atmosphere-ocean-sea ice interactions may affect primary production. The predicted decrease in sea-ice extent will reduce the total marginal ice zone area, which is then expected to decrease productivity in the marginal ice zone. However, this will depend on the interplay between changes in in situ irradiance, stratification, and surface mixing (Arrigo \& Thomas, 2004; Arrigo et al., 2008). Also, wave-sea ice interactions contribute to increasing the marginal ice zone (Massom \& Stammerjohn, 2010), which may give rise to greater marginal ice zone habitat in future because of increasing winds. The prognosis is currently unknown and will depend on the time scales of interest. The removal of ice in the past few decades in the west Antarctic Peninsula has resulted in deeper mixed layers and a consequent reduction in available irradiance, decreased phytoplankton biomass and size, and reduced productivity (Montes-Hugo et al., 2009; Venables et al., 2013). However, the timing of the bloom was not related to winter sea-ice extent but more to the seasonal cycle of irradiance (Venables et al., 2013).

Reduced productivity might be transient. Increased atmospheric temperatures are expected not only to increase heat input to the surface waters but also to increase meltwater from coastal sources, both of which could enhance production from increased metabolism, the increased stratification and input of iron reservoirs from the ice sheet (Dierssen et al., 2002; Boyd \& Ellwood, 2010; Gerringa et al., 2012). 
Ocean acidification notably affects shell thickness in calcifying protists such as foraminifera (Moy et al., 2009). More generally, it is expected to increase the energetic costs of calcification (Shi et al., 2010; Hoffmann et al., 2012), change the availability of nutrients and affect cell physiology (Orr et al., 2005; Shi et al., 2010; Byrne, 2011; Bednaršek et al., 2012b). However, the responses of marine microbes to ocean acidification are difficult to predict because of multiple interacting environmental stressors combined with indirect feedbacks within the complex microbial food web (Boyd, 2011). Viruses are relatively unaffected by $\mathrm{CO}_{2}$ concentrations (Larsen et al., 2008), but are likely to be affected indirectly by host organisms becoming more vulnerable to infection (Danovaro et al., 2011). Activities of some bacterial hydrolytic enzymes decreased with acidification (Yamada \& Suzumura, 2010), suggesting that bacterial respiration of some substrates may decline due to ocean acidification. Enhanced $\mathrm{CO}_{2}$ may promote growth in large diatoms (Engel et al., 2008; Tortell et al., 2008; Feng et al., 2009), however nanoplankton have been found to be more successful than diatoms under enhanced $\mathrm{CO}_{2}$ conditions in natural communities in the Bering Sea (Hare et al., 2007). The potential for differential responses to enhanced $\mathrm{CO}_{2}$ between phytoplankton functional groups in the Southern Ocean has not yet been determined.

\section{Zooplankton and salps}

Atkinson et al. (2012b) reviewed the different zooplankton functional groups in the Southern Ocean (copepods, euphausiids, salps, Themisto gaudichaudii, pteropods, appendicularians, carnivorous macroplankton), noting that few studies have investigated their thermal tolerances and metabolic behaviours. Zooplankton assemblages are closely related to the different frontal zones in the Southern Ocean (Hunt \& Hosie, 2005, 2006a,b; Pinkerton et al., 2010; Ward et al., 2012; Hosie et al., 2014). Shifts in the fronts are expected to result in concomitant changes in zooplankton distributions.

Reanalysis of historical data and comparisons of results from the Discovery Investigations with presentday studies showed equivocal results in terms of changes in the relative importance or distribution of zooplankton taxa in the Drake Passage, Antarctic Peninsula and southwest Atlantic (Ward et al., 2008; Takahashi et al., 2010). Mackey et al. (2012) combined historical data (1928-1935) from the Discovery Investigations to investigate the relationship between macrozooplankton abundance in the Atlantic sector and water temperature. They then used this relationship to model the effect of the observed $>1{ }^{\circ} \mathrm{C}$ rise in water temperature in this region (Meredith \& King, 2005;
Whitehouse et al., 2008), on the distributional ranges of various taxa. A modelled uniform $1{ }^{\circ} \mathrm{C}$ temperature rise produced a pole-ward shift for all taxa analysed, which ranged across all groups reviewed by Atkinson et al. (2012b). These authors predicted that widespread polar/subpolar species, which have a wider thermal tolerance, would appear $4-12^{\circ}$ in latitude further south. In contrast, sub-Antarctic taxa with a narrower tolerance were less likely to extend their range southward because of the steep temperature gradient across the Antarctic Polar Front.

Salps are omnivorous filter feeders, feeding mostly on smaller phytoplankton. Traditionally they were understood to avoid sea ice and only occur in areas where Antarctic krill typically dominates when krill abundance is low (Loeb et al., 1997). More recently though, salps and krill have been found to co-occur in areas where sea ice has declined in the west Antarctic Peninsula, and salps have been calculated to be the major grazers on phytoplankton where the salps bloom in those areas (Bernard et al., 2012). The degree to which salps become prominent in future remains uncertain because the drivers of their abundance have not been elucidated. However, salps and krill are adapted to be successful in different environments, namely open ocean and coastal regions respectively. In regions with complex oceanography (e.g. off the Antarctic Peninsula, within the Marginal Ice Zone and polynyas), salps and krill may coexist for short periods but their respective habitat requirements may be important in keeping salps and krill spatially separated in the long term. Low temperature and high particulate concentrations associated with sea-ice retreat may keep salps from invading the high Antarctic regions (Pakhomov et al., 2002).

Calcifying zooplankton, such as the pelagic molluscan pteropods, are vulnerable to ocean acidification, although the degree to which they will be affected is yet to be determined (Roberts et al., 2011a; Bednaršek et al., 2012b).

\section{Krill}

Antarctic krill is the dominant herbivore in many parts of the Southern Ocean and the major route for transfer of carbon between primary producers and upper-trophic levels (Murphy et al., 2012a). The life cycle of krill is tightly linked to the seasonality of the Antarctic environment (e.g. timing, duration and characteristics of sea ice, photoperiod, and temperature; Nicol, 2006; Kawaguchi et al., 2007). The distribution of Antarctic krill and the 'krill-based' food web is influenced by the winter extent of sea ice, as krill is positively dependent upon sea ice for reproduction, survival and recruitment 
(Kawaguchi \& Satake, 1994; Siegel \& Loeb, 1995; Nicol, 2006; Murphy et al., 2007a; Wiedenmann et al., 2009; Flores et al., 2012). The Southern Boundary of the ACC also appears to be an important factor as it aligns with much of the northern extent of the range of Antarctic krill except in the Atlantic sector, where this boundary extends further to the north (e.g. Nicol, 2006; Atkinson et al., 2009; Jarvis et al., 2010). Antarctic krill tend to cooccur with their main food source, large diatoms (e.g. Bernard et al., 2012); other dominant herbivores, such as salps and copepods, exploit smaller size classes of phytoplankton (Moline et al., 2004).

Importantly, different life stages of Antarctic krill will experience different changes in the physical environment because each life stage predominantly occurs in a different habitat. Eggs and early larvae experience diverse physical conditions as they descend to deep water then rise in the water column, while mid-late larvae and juveniles are thought to depend on the sea-ice environment for growth and survivorship, and subadults and adults generally live in areas where juveniles are less frequently found (Nicol, 2006; Meyer, 2012). Postlarval krill may also experience different environmental conditions as a result of advection either by transport in currents (Murphy et al., 2004; Fach et al., 2006; Quetin et al., 2007; Piñones et al., 2011), or in association with sea-ice movement (Murphy et al., 2007b; Thorpe et al., 2007).

Antarctic krill densities are reported to have declined in the Scotia Sea by approximately 30\% since the 1980s (Atkinson et al., 2004), in parallel with decreases in extent and duration of winter sea ice. However, the degree to which the overall abundance of krill has declined is still a matter of considerable debate (e.g. Nicol \& Brierley, 2010; Atkinson et al., 2012a). The combined effects of changes in sea-ice extent, ocean chemistry, temperature and food abundance and/or distribution on Antarctic krill have not yet been investigated, and the overall prognosis for krill populations is ambiguous. In addition, the prognosis will be affected by changes in the food web, such as from the recovery of whale populations (Murphy et al., 2012a).

Krill may respond to warming with an increased metabolic rate although the overall growth rate of individuals will depend on food supply. Increased temperatures in the Antarctic Peninsula region may enhance krill productivity provided that metabolic requirements do not exceed ingestion rates (and that food is available). However, the response is likely to be negative around South Georgia where water temperatures in this area have already increased (Mackey et al., 2012), as further temperature increases could cause metabolic costs to rise to a level where they are not sustainable (Murphy et al., 2007a; Wiedenmann et al., 2008; Hill et al., 2013). Such spatial variability in factors influencing krill populations is likely to result in region-specific responses. These responses may be further affected by the (as yet unknown) potential of krill to adapt physiologically and behaviourally. For example, it has been shown that krill can exploit the full depth of the ocean, and thus their potential habitat is far greater than once thought (Schmidt et al., 2011).

Krill may be susceptible to increasing UV-B compared to other Antarctic organisms, based on DNA base composition (Jarman et al., 1999), but at the same time their ability to acquire compounds that provide protection against UV exposure (Newman et al., 2000), and their behavioural response to UV-A, would reduce their exposure to UV-B and therefore the risk of UV-B damage to DNA (Newman et al., 2003). A significant correlation between krill density and Antarctic ozone depletion in the Antarctic Peninsula region has been reported suggesting direct and/or indirect UV impacts on krill density (Naganobu et al., 1999).

Recent research combining experimental results and ocean circulation modelling indicates that the survival of krill embryos may be negatively affected by increasing ocean acidity (Kawaguchi et al., 2011). These effects were manifested within the range of acidification that is projected to occur over the depth range that krill embryos are exposed to during their development (Kawaguchi et al., 2013). Further study is needed for all other life stages along with the combined effects of acidification with other environmental stressors to improve understanding of the overall impacts of climate change on the life history of krill.

Finally, the Antarctic krill fishery may play an increasingly important role in influencing krill populations in coming years. This fishery has significant opportunity for expansion, and could become the largest fishery in the world (Nicol \& Endo, 1997; Nicol et al., 2012). Krill fishing activity has been affected by changes in sea-ice extent around the Antarctic Peninsula (Everson \& Goss, 1991; Kawaguchi et al., 2006). Fishing was initially restricted to summer and autumn, but since the mid-1990s operations have occurred yearround due to the extended ice-free season (Kawaguchi et al., 2006, 2009).

\section{Fish $\mathcal{E}$ cephalopods}

The Southern Ocean is characterized by high macroscale endemism of fish species - especially the neritic Notothenioids ( $86 \%$ of which are endemic). This endemism is due to the major oceanic fronts barring meridional dispersal combined with the geographic isolation of sub-Antarctic islands (Eastman \& McCune, 2000). Notothenioids are the most abundant fish fauna over 
continental and island shelves, and seamounts (Kock, 1992). On the Antarctic continental shelf, the Antarctic silverfish, Pleuragramma antarcticum, dominates the neritic fish fauna. Its eggs and larvae are strongly associated with sea ice. Antarctic toothfish, Dissostichus mawsoni, and Patagonian toothfish, D. eleginoides occur over the continental shelf, and on the margins and slopes of sub-Antarctic shelves, respectively. Mackerel icefish, Champsocephalus gunnari, occur in shelf areas less than $500 \mathrm{~m}$ in depth and many localized subpopulations have been identified throughout the range of this species (Kock \& Everson, 1997).

In the oceanic zone, myctophids and bathylagids dominate (Gjøsaeter \& Kawaguchi, 1980; Hulley, 1981; Collins et al., 2012). Distributions of species in these families show a high degree of correlation with depth and many are closely associated with oceanographic features, particularly frontal zones. Krefftichthys anderssoni and Gymnoscopelus braueri are the most abundant species in the Polar Frontal Zone, while Electrona antarctica, G. braueri, and Bathylagus spp. dominate south of this area to the continental shelf/ice edge (see Collins et al., 2012). These fishes, along with Antarctic silverfish and mackerel icefish, constitute the midtrophic level between mesozooplankton and many top predators (seabirds, marine mammals, large fish, and cephalopods) and may provide alternative energy pathways (Murphy et al., 2013).

Projected changes for Southern Ocean fish under the impacts of climate change are unclear and any shifts in the future will need to be interpreted with respect to the potential confounding effects of fisheries. A southward movement of Southern Ocean frontal systems is expected to cause southward shifts in the distributions of myctophid species, given their strong association with fronts (Hulley, 1981; Collins et al., 2012). It could also result in isolated populations restricted to island shelves becoming locally extinct, if they are unable to adapt to warmer ocean temperatures. Similarly, icefish could be vulnerable to ocean warming around currently productive sub-Antarctic islands because of their limited distribution and reliance on highly oxygenated cold water as they lack haemoglobin (Kock \& Everson, 1997; Near et al., 2012).

Postlarval toothfish are generalist predators (Roberts et al., 2011b) that can migrate over large distances and occupy a very broad range of depths (from the nearshore to at least $2500 \mathrm{~m}$; Hanchet et al., 2008; Collins et al., 2010; Duhamel et al., 2011; Welsford et al., 2011). Hence, toothfish might be relatively resilient to environmental change by being able to descend or move to more favourable areas. However Antarctic toothfish has antifreeze glycoproteins in its blood that are not present in Patagonian toothfish, and the ecology of early life stages of both species is poorly understood; there are known environmental relationships affecting toothfish recruitment (Belchier \& Collins, 2008), so toothfish may also be vulnerable to a changing environment. These factors are likely to be important in governing the responses of these species to change. The extent of thermal habitat preferred by $D$. mawsoni may contract over the next 30 years (Cheung et al., 2008), but the data used to generate these scenarios excluded the Ross Sea, which is an area of high abundance of this species and currently increasing annual sea-ice extent.

Finfish fisheries may have greater access to stocks from reductions in sea-ice extent and a shortening of the sea-ice season. At present, fisheries for Antarctic toothfish around the Antarctic continent are limited to a summer season because of the difficulty of accessing the primary fishing grounds on the continental slope, which are covered by sea ice for much of the year.

Squid are important in Southern Ocean food webs (Murphy et al., 2012a). This is mostly known from the prevalence of squid in the diet of many top predators, often identified from squid beaks (Xavier \& Cherel, 2009). Nevertheless, there are major gaps in our current knowledge of their ecology (Collins \& Rodhouse, 2006). Predicted temperature increases for the coming 100 years are unlikely to have major effects on squid in the Southern Ocean other than changes in distribution near the limits of their range (Rodhouse, 2012).

\section{Marine mammals and seabirds}

Seabirds and marine mammals are some of the best studied taxa in the Southern Ocean. Many possible taxa-specific responses to climate change, including those resulting from habitat dependencies, tolerances and adaptability, and changes in food availability, have been described (Trathan et al., 2007). For example, foraging and reproductive success may be impacted by changes to sea ice, which is an important feeding and breeding habitat for crabeater seals Lobodon carcinophagus (Ducklow et al., 2007, 2012a; Costa et al., 2010), but could impede foraging for some penguin populations (Emmerson \& Southwell, 2008; Massom et al., 2009). Other factors not related to foraging may also be important. For example, increased snow precipitation which accumulates in breeding colonies can decrease survival of chicks of Adélie penguins when accompanied by reduced food supply (Chapman et al., 2011).

Responses of marine mammals and birds to variability in the physical environment in the ASO have been considered at both regional and circumpolar scales (Ainley et al., 2005, 2010). However, populations of the same species may not be responding in a uniform way around Antarctica because of regional differences in 
changes to the physical environment. While many species have been responding negatively to warmer conditions (e.g. Barbraud \& Weimerskirch, 2001, 2003; Fraser \& Hofmann, 2003; Jenouvrier et al., 2003, 2005b; Xavier et al., 2003; Forcada et al., 2005, 2006; Lea et al., 2006; Trathan et al., 2007; Costa et al., 2010; McIntyre et al., 2011; Barbraud et al., 2012), some species are responding positively in some regions. For example, in the rapidly warming west Antarctic Peninsula region populations of Adélie penguins (Pygoscelis adeliae) have been declining, apparently due to decreases in sea-ice extent (e.g. Trivelpiece et al., 2011; Ducklow et al., 2012a; Lynch et al., 2012). These reductions in Adélie penguin populations are in contrast with population increases in the Ross Sea and some parts of eastern Antarctica (Ainley et al., 2005; Jenouvrier et al., 2006; Kato \& Ropert-Coudert, 2006; Smith et al., 2012) where patterns of sea-ice change and variability are quite different (Massom et al., 2013).

Trends in marine mammal populations are known only for a few species. At South Georgia in the Atlantic sector, Antarctic fur seal (Arctocephalus gazella) populations have been increasing rapidly since their commercial exploitation during the 19th century, but now show a strong negative response to an increasingly warm environment (Forcada et al., 2005, 2008). In the western Antarctic Peninsula sightings of Weddell seals have declined while sightings of Antarctic fur seals and elephant seals have increased (Siniff et al., 2008). Few reliable estimates of trends in depleted whale populations are available but humpback whales are known to be increasing rapidly (Zerbini et al., 2010).

Long-term downward trends in the populations of some seals and seabirds in the subantarctic of the Indian and Pacific sectors of the Southern Ocean have been interpreted as a region-wide shift to a system with lower productivity (Weimerskirch et al., 2003; Jenouvrier et al., 2005b; ; Lea et al., 2006; McMahon et al., 2009), although comparative data on prey abundances are not yet available. Similarly, changes in the abundance of seabird populations on the coast of Adélie Land in eastern Antarctica and shifts in their breeding phenology may be related to climate events and climate change impacts (Barbraud \& Weimerskirch, 2006; Hindell et al., 2003, 2012; Jenouvrier et al., 2005b, 2009). At other locations with similar monitoring programmes in East Antarctica, there are currently no obvious phenological changes for some species (Emmerson et al., 2011).

Flying seabirds, such as albatrosses and petrels, may be less constrained than penguins in their foraging range during the breeding season. While these birds respond to climate variability (Inchausti et al., 2003; Jenouvrier et al., 2005a; Barbraud \& Weimerskirch, 2006; Nevoux et al., 2010; Péron et al., 2010; Rivalan et al., 2010; Rolland et al., 2010; Barbraud et al., 2011; Weimerskirch et al., 2012), the underlying ecological mechanisms of these effects are not clear.

The interpretation of changes in marine mammal and seabird populations in the Southern Ocean needs to incorporate the potential population- and system-level effects of past exploitation (Murphy, 1995; Murphy \& Hofmann, 2012). The near extirpation of Antarctic fur seals and baleen whales through commercial sealing and whaling in the nineteenth and twentieth centuries was a major perturbation to the Southern Ocean ecosystem as these species represented the dominant krillfeeding predator biomass. Decreases in albatross and petrel populations are due to incidental mortality in long-line fisheries in southern and temperate waters where these birds forage (Weimerskirch et al., 1997; Tuck et al., 2001; Arnold et al., 2006). Recovery of these populations and/or continued fishery mortality will make interpretations of change more difficult because of the potential confounding effects between recovery/ fishery mortality and other causes of ecosystem change (Croxall et al., 2002; Trathan \& Reid, 2009; Rolland et al., 2010; Barbraud et al., 2012; Trathan et al., 2012). Further, competitive interactions and predation may constrain the recovery of some populations (Trivelpiece et al., 2011; Schwarz et al., 2013).

Changes in habitat location and/or quality may affect the foraging success of marine mammals and seabirds, depending on how much their foraging ranges need to change and the time when preferred prey are available. Capital breeding enables animals to forage widely and accumulate and store energy prior to giving birth, and then provision young using stored body reserves (Drent \& Daan, 1980; Costa, 1993). Mysticete cetaceans and most phocid seals are extreme capital breeders (Costa, 1993; Lockyer, 2007), and often use foraging grounds that are spatially and temporally separate from breeding areas, thereby disassociating reproductive success from local food availability. The other strategy is income breeding where food needs to be accessed and delivered to the young immediately. The remaining marine mammals and all seabirds have this strategy as they forage more or less continuously during pup or chick rearing and must return to breeding colonies to nourish their offspring (Costa \& Shaffer, 2012), thus linking reproductive success with local prey abundance (Costa, 1993; Forcada et al., 2005; Lea et al., 2006; Trathan et al., 2006; Costa \& Shaffer, 2012). Most albatrosses and petrels are a potential exception due to their wide foraging range (Forcada \& Trathan, 2009; Costa \& Shaffer, 2012; Weimerskirch et al., 2012).

Income breeders are particularly susceptible to effects of climate change when they are tied to land-based colonies during breeding. If prey availability decreases 
within the breeding foraging range then breeding success will decline (Costa, 2008; Forcada \& Trathan, 2009). For example, for king penguins (Aptenodytes patagonicus) on Îles Crozet in the Indian Sector of the Southern Ocean, foraging habitat models and climate models project a doubling of the distance to reach optimal foraging zones, far beyond the usual foraging range for this species (Péron et al., 2012). Not all ASO islands are suitable for sub-Antarctic land-based predators, which limits opportunities to move to alternative breeding sites that would also need to be within reach of predictable prey resources (Xavier et al., 2003).

\section{Benthos}

Antarctic benthos exists in a physical environment that in some respects (e.g. temperature, salinity) is very stable, but in other aspects (e.g. irradiance, physical disturbance, seasonal flux of primary productivity) can be highly variable (Kaiser et al., 2013). Impacts of climate change on ASO benthos will differ between habitats on the continental shelf, slope and in the deep sea (Brandt \& Gutt, 2011). Ice scour down to depths of $500 \mathrm{~m}$ (the extreme limit) is the major form of disturbance on benthic shelf communities (Gutt \& Piepenburg, 2003; Smale \& Barnes, 2008; Smale et al., 2008). Increased scour will increase patchiness of shallower shelf areas and, thus, increase the prevalence of early successional species, with associated changes in ecosystem composition and function (Clarke et al., 2007). For example, the survivorship of some longer-lived species will be reduced, such as for the bryozoan Fenestrulina rugula (Barnes \& Souster, 2011). In the last 12 years the chances of $F$. rugula colonies reaching 2 years of age and reproducing have halved as a result of iceberg scouring. The most likely response to increased ice disturbance of typical Antarctic species would be a slight shift in distribution, resulting in a contraction of species' bathymetric ranges to deeper areas (Smale \& Barnes, 2008).

Change in the ice environment may have the most significant effects on benthic assemblages through change in seasonal production of phytoplankton, which may in turn alter the magnitude, timing, quality, and duration of the seasonal pulse of phytodetrital rain from the spring bloom (Ingels et al., 2012; Lohrer et al., 2013). Some invertebrates time their reproduction to the spring bloom, such as some filter feeding holothurians (Gutt et al., 1992) and peracarid crustaceans (Pearse et al., 1991; Baird \& Stark, 2013). Change in surface production may arise through collapse of ice shelves (Peck et al., 2010), enabling benthic taxa to colonize these areas (Gutt et al., 2011, 2013). Changes to benthicpelagic coupling will arise but the outcomes are unpredictable at this stage. While surface production may increase with the loss of ice shelves and sea ice, changes of the microbial assemblages to smaller phytoplankton and, thus, smaller zooplankton could give rise to greater recycling of nutrients in the surface layers and less export of organic matter to the benthos.

Benthic macroalgae contribute significantly to Antarctic coastal food webs, both directly and as detritus (Heywood \& Whitaker, 1984; Wiencke, 1996; Gillies et al., 2012). Ice disturbance in shallow waters seems likely to select for fast growing macroalgal species with low competitive capability; increased ice disturbance may therefore change both the species richness and biomass of Antarctic macroalgal assemblages (Quartino et al., 2001). These algae are likely to benefit from the greater light, warming and increased nutrient loads from meltwater (Wiencke, 2010). As a result, shallow water benthic communities may become dominated by macroalgae, with concomitant reductions in biodiversity (Clark et al., 2013). Several cold temperate macroalgal species have already been reported in Antarctic waters (Müller et al., 2011). These introductions may be a result of transport on ships rather than migrations as the ACC still forms a barrier to dispersal from more temperate-subantarctic locations to higher latitudes.

Benthic animals may be vulnerable to change in temperature (Barnes \& Peck, 2008). Most experiments have shown that polar benthic species have less capacity for tolerance than species elsewhere; many species are unable to perform essential functions when temperatures are raised only $2-3{ }^{\circ} \mathrm{C}$ (e.g. swimming in scallops or burying in infaunal bivalve molluscs) and mortality is induced in some species by temperature increases of $5-10{ }^{\circ} \mathrm{C}$ above normal conditions (Peck, 2005). Antarctic species are so sensitive to temperature change that an increase in temperature of $2{ }^{\circ} \mathrm{C}$ has been theorized to cause population or species removal from the Southern Ocean (Peck et al., 2004).

Calcified marine macroinvertebrates and coralline algae are a significant component of benthic communities in Antarctica (Amsler et al., 1995; Clarke \& Johnston, 2003). The potential effects of ocean acidification in benthic ecosystems at high latitudes are poorly understood; there is very little experimental evidence of impacts on benthic invertebrates, although a number of studies have considered possible dissolution of skeletons (Orr et al., 2005; McClintock et al., 2009), and reduced success of fertilization and early life-history stages in invertebrates (Hofmann et al., 2010; Byrne, 2011; Ericson et al., 2012).

\section{Conclusions}

The general prognosis for Antarctic and Southern Ocean marine habitats under increased climate change 
is for an overall warming and freshening of the present-day system, strengthening of westerly winds, with a potential pole-ward movement of those winds and the frontal systems, and an increase in eddy activity. There will be regional variability in many habitat parameters, including in sea ice. Notably, the future seasonal variation in habitat conditions will not be consistent with the current seasonal cycle, which may impact the timing and magnitude of primary production and, thus, have consequences for other species depending on the spring bloom.

The known responses of individual taxa to these changes in the physical environment are summarized in this article (Table 1). These responses will be governed by how easily the taxa can tolerate change within existing physiological flexibility, adapt to new environmental regimes or migrate to alternative sites that enable survival. Further, vulnerability of marine biota in the Southern Ocean to disease may be important but is currently not well understood (Kerry \& Riddle, 2009). The ultimate consequences of such changes are not well understood; they are expected however to go beyond shifts in species ranges and possibly may result in novel functional organization and dynamics of ASO food webs and reduced biodiversity.

Our review indicates that microbes and zooplankton are expected to generally move south as the ocean conditions in which they are normally found move south,

Table 1 Summary of known direct responses of biota to changes in physical parameters in Antarctica and the Southern Ocean. $\mathrm{PAR}=$ photosynthetically active radiation, $\mathrm{UV}=$ ultraviolet radiation. Acidification includes altered carbonate chemistry and $\mathrm{pH}$. Sea ice includes consideration of thickness, concentration, and extent without differentiating the factor/s causing change in each group of organisms. The symbols used in the table denote a positive (+) or negative (-) direct effect of an increase in the physical variable on particular taxa (see text for details as to the reasons). '?' indicates where there is likely to be a response but the direction is uncertain, i.e. the result may be variable in space, time or for specific taxa or the evidence is equivocal

\begin{tabular}{|c|c|c|c|c|c|c|c|c|}
\hline Taxon & PAR & UV & Temperature & $\begin{array}{l}\text { Ocean } \\
\text { acidification }\end{array}$ & $\begin{array}{l}\text { Mixed } \\
\text { layer } \\
\text { depth }\end{array}$ & Sea ice & $\begin{array}{l}\text { Move } \\
\text { with } \\
\text { fronts }\end{array}$ & Eddies \\
\hline Diatoms & $\begin{array}{l}+\left(<3{ }^{\circ} \mathrm{C}\right) \\
-\left(>3{ }^{\circ} \mathrm{C}\right)\end{array}$ & - & + & & + & - & + & \\
\hline Flagellates, Phaeocystis & - & + & - & & - & - & + & \\
\hline Microzooplankton & & $?$ & + & $?$ & & - & + & \\
\hline Bacteria \& viruses & & - & + & & & - & + & \\
\hline Zooplankton & & & + & & & & + & \\
\hline Salps & & & & & & - & + & \\
\hline Antarctic krill & & - & $\begin{array}{l}+ \text { antarctic } \\
\text { - subantarctic }\end{array}$ & - & & + & & \\
\hline Nototheniid fish & & & - & & & & & \\
\hline Myctophid fish & & & + & & & & + & \\
\hline Oegopsid squid & & & $?-$ & $?-$ & & & & \\
\hline Southern Elephant seal & & & & & & $?$ & & + \\
\hline Antarctic Fur seal & & & & & - & $?+$ & + & + \\
\hline Crabeater/Weddell seals & & & & & & + & & \\
\hline King penguin & & & & & & & + & + \\
\hline Emperor penguin & & & & & & $?$ & & $?$ \\
\hline Adélie penguin & & & & & $?$ & $\begin{array}{l}+ \text { no ice to lower } \\
\text { ice conditions } \\
\text { - heavy ice } \\
\text { conditions }\end{array}$ & & \\
\hline Chinstrap penguin & & & & & ? & + & & \\
\hline Macaroni penguin & & & & & & - & & + \\
\hline Baleen Whales & & & & & & $?$ & & $?$ \\
\hline Wandering Albatross & & & & & & & + & + \\
\hline Black-browed Albatross & & & & & & + & + & \\
\hline Antarctic fulmar & & & & & & + & $?$ & $?$ \\
\hline Benthos & & & - & & & & & \\
\hline Macroalgae & + & & & & & & & \\
\hline $\begin{array}{l}\text { Calcifying benthic } \\
\text { invertebrates }\end{array}$ & & & & - & & & & \\
\hline
\end{tabular}


although their timing of maximum seasonal production may alter depending on changes in nutrient supply, mixed layer depth and the timing of the sea-ice advance and retreat relative to day length. For Antarctic krill and finfish, which have the means to move large geographic distances, the latitudinal breadth of their range will depend on the degree to which they can tolerate warming oceans and changes to productivity in the areas in which they currently live. These tolerances are largely unknown.

An overarching issue for invertebrates and fish is how the acidity of seawater may affect calcification and reproductive physiology of these organisms. Evidence to date suggests that calcifiers are being affected, and Antarctic krill may be affected by the predicted range of change in $\mathrm{pH}$ over the next 100 years. For Antarctic shelf and deep-sea benthos, ocean acidification is likely to be the most important change in their habitat over the coming century.

For marine mammals and birds, the expected changes primarily relate to their flexibility in moving to alternative locations for food and the energetic cost of longer or more complex foraging trips, if they are bound to breeding colonies in summer. At present, the effects on these species appear variable because of regional differences in changes in the physical environment that might impact on foraging trip duration; for example, how the sea-ice pack might impact breeders constrained to the Antarctic coast or the distance of frontal systems and eddies (that are used for foraging) from sub-Antarctic islands. An additional factor requiring consideration is whether suitability and/or availability of land-based breeding sites is changing.

For Antarctica and the Southern Ocean, comprehensive species-specific vulnerability assessments are difficult. Many of the changes reviewed here will be compounded by the indirect food-web effects that will ensue. Nevertheless, climate change will not just impact primary producers, but can impact directly the habitats and ecologies of species at different trophic levels causing changes to both bottom-up and top-down forcings in the ecosystem.

To better assess the autoecological responses of these species to habitat change, and how these responses need to be factored into ecological models for the region, the following variables need to be estimated for key species:

1. Physiological responses of primary producers to the expected physical conditions in the Southern Ocean, particularly near to the Antarctic continent;

2. Constraints to growth and reproduction of invertebrates, given local conditions such as production and temperature;
3. The relative importance of winter vs. summer food acquisition on the reproductive performance of marine mammals and birds; and

4. The cost to land-based predators of shifts in optimal locations of prey.

Here, we review the autecological responses of organisms to climate change impacts in Antarctica and the Southern Ocean. While this relates to tolerances and ecological adaptability of taxa, a gap in knowledge is how well species may respond evolutionarily to the rapid changes occurring in these ecosystems (Turner et al., 2009a, 2013). If evolutionary adaptation is not possible and refugia are not available then those species that are cold-adapted or restricted to particular habitats that are declining may be lost.

A great challenge for Antarctic and Southern Ocean science is to develop methods for assessing current and future impacts of climate change on ecosystem structure and function. Particular challenges lie in evaluating regional differences in the rate and direction of responses, and in integrating knowledge on the species-level responses but also the indirect effects that may be promulgated through the food web. This review provides a first step towards addressing these challenges by synthesizing current knowledge and identifying key uncertainties and vulnerabilities for Antarctic marine species and functional groups.

\section{Acknowledgements}

This article was a product of the 2nd international Southern Ocean Sentinel workshop in Hobart Australia in May 2012 as part of the IMBER program, Integrating Climate and Ecosystem Dynamics (ICED) of the Southern Ocean. Thank you to all the participants at the workshop and others in the ICED community for discussions surrounding the prognoses for climate change impacts in the region.

The OISST CDR used in this article was acquired from NOAA's National Climatic Data Center (http://www.ncdc. noaa.gov). This CDR was originally developed by Richard Reynolds and colleagues for the NOAA's CDR Program. Satellite sea-ice concentration data were obtained from the NASA Earth Observing System Distributed Active Archive Center (DAAC) at the US National Snow and Ice Data Center, University of Colorado, Boulder (http:/ / www.nsidc.org).

This article was supported by the Australian Government's Cooperative Research Centres Programme through the Antarctic Climate and Ecosystems Cooperative Research Centre (ACE CRC), the Australian Antarctic Division and ICED.

\section{References}

Abram N, Wolff EW, Curran MAJ (2013) A review of sea ice proxy information from polar ice cores. Quaternary Science Reviews, 79, 168-183.

Ackley SF, Wadhams P, Comiso JC, Worby AP (2003) Decadal decrease of Antarctic sea ice extent inferred from whaling records revisited on the basis of historical and modern sea ice records. Polar Research, 22, 19-25. 
Ainley DG, Clarke ED, Arrigo K, Fraser WR, Kato A, Barton KJ, Wilson PR (2005) Decadal-scale changes in the climate and biota of the Pacific sector of the Southern Ocean, 1950s to the 1990s. Antarctic Science, 17, 171-182.

Ainley D, Russell J, Jenouvrier S, Woehler E, Lyver PO, Fraser WR, Kooyman GL (2010) Antarctic penguin response to habitat change as Earth's troposphere reaches 2 degrees $C$ above preindustrial levels. Ecological Monographs, 80, 49-66.

Amsler CD, Rowley RJ, Laur DR, Quetin LB, Ross RM (1995) Vertical distribution of Antarctic Peninsular macroalgae: cover, biomass and species composition. Phycologia, 34, 424-430

Arnold JM, Brault S, Croxall JP (2006) Albatross populations in peril: a population trajectory for black-browed albatrosses at South Georgia. Ecological Applications, 16, 419-432.

Arrigo K, Thomas D (2004) Large scale importance of sea ice biology in the Southern Ocean. Antarctic Science, 16, 471-486.

Arrigo KR, Van Dijken GL (2003) Phytoplankton dynamics within 37 Antarctic coastal polynya systems. Journal of Geophysical Research-Oceans, 108, 3271-3271.

Arrigo KR, Robinson DH, Worthen DL, Dunbar RB, Ditullio GR, Vanwoert M, Lizotte MP (1999) Phytoplankton community structure and the drawdown of nutrients and $\mathrm{CO}_{2}$ in the Southern Ocean. Science, 283, 365-367.

Arrigo KR, Van Dijken GL, Bushinsky S (2008) Primary production in the Southern Ocean, 1997-2006. Journal of Geophysical Research, 113, C08004.

Arrigo KR, Mock T, Lizotte MP (2010) Primary producers in sea ice. In: Sea Ice, 2nd edn (eds Thomas DN, Dieckman GS), pp. 283-326. Wiley-Blackwell, New York (USA) and Oxford (UK).

Arrigo KR, Perovich DK, Pickart RS et al. (2012) Massive phytoplankton blooms under Arctic sea ice. Science, 336, 1408-1408.

Arzel O, Fichefet T, Goosse H (2006) Sea ice evolution over the 20th and 21st centuries as simulated by current AOGCMs. Ocean Modelling, 12, 401-415.

Atkinson A, Siegel V, Pakhomov E, Rothery P (2004) Long-term decline in krill stock and increase in salps within the Southern Ocean. Nature, 2996, 1-4.

Atkinson A, Siegel V, Pakhomov EA, Jessopp MJ, Loeb V (2009) A re-appraisal of the total biomass and annual production of Antarctic krill. Deep-Sea Research Part I-Oceanographic Research Papers, 56, 727-740.

Atkinson A, Nicol S, Kawaguchi S et al. (2012a) Fitting Euphausia superba into Southern Ocean food-web models: a review of data sources and their limitations. CCAMLR Science, 19, 219-245.

Atkinson A, Ward P, Hunt BPV, Pakhomov EA, Hosie GW (2012b) An overview of Southern Ocean zooplankton data: abundance, biomass, feeding and functional relationships. CCAMLR Science, 19, 171-218

Baird HP, Stark JS (2013) Population dynamics of the ubiquitous Antarctic benthic amphipod Orchomenella franklini and its vulnerability to environmental change. Polar Biology, 36, 155-167.

Barber DG, Massom RA (2007) A bi-polar assessment of modes of polynya formation. In: Polynyas: Windows to the World (eds Smith WO, Barber DG), pp. 1-54. Elsevier Amsterdam.

Barbraud C, Weimerskirch H (2001) Emperor penguins and climate change. Nature, 411, 183-186.

Barbraud C, Weimerskirch H (2003) Climate and density shape population dynamics of a marine top predator. Proceedings of the Royal Society of London Series B-Biological Sciences, 270, 2111-2116.

Barbraud C, Weimerskirch H (2006) Antarctic birds breed later in response to climate change. Proceedings of the National Academy of Sciences of the United States of America, 103, 6248-6251.

Barbraud C, Rivalan P, Inchausti P, Nevoux M, Rolland V, Weimerskirch H (2011) Contrasted demographic responses facing future climate change in Southern Ocean seabirds. Journal of Animal Ecology, 80, 89-100.

Barbraud C, Rolland V, Jenouvrier S, Nevoux M, Delord K, Weimerskirch H (2012) Effects of climate change and fisheries bycatch on Southern Ocean seabirds: a review. Marine Ecology Progress Series, 454, 285-307.

Barnes D, Peck L (2008) Vulnerability of Antarctic shelf biodiversity to predicted regional warming. Climate Research, 37, 149-163.

Barnes DKA, Souster T (2011) Reduced survival of Antarctic benthos linked to climate-induced iceberg scouring. Nature Climate Change, 1, 365-368.

Bednaršek N, Tarling GA, Bakker DCE et al. (2012a) Extensive dissolution of live pteropods in the Southern Ocean. Nature Geoscience, 5, 881-885.

Bednaršek N, Tarling GA, Bakker DCE et al. (2012b) Description and quantification of pteropod shell dissolution: a sensitive bioindicator of ocean acidification. Global Change Biology, 18, 2378-2388.

Belchier M, Collins M (2008) Recruitment and body size in relation to temperature in juvenile Patagonian toothfish (Dissostichus eleginoides) at South Georgia. Marine Biology, 155, 493-503.
Bernard KS, Steinberg DK, Schofield OME (2012) Summertime grazing impact of the dominant macrozooplankton off the Western Antarctic Peninsula. Deep Sea Research Part I: Oceanographic Research Papers, 62, 111-122.

Bintanja R, Van Oldenborgh GJ, Drijfhout SS, Wouters B, Katsman CA (2013) Important role for ocean warming and increased ice-shelf melt in Antarctic sea-ice expansion. Nature Geoscience, 6, 376-379.

Böning CW, Dispert A, Visbeck M, Rintoul SR, Schwarzkopf FU (2008) The response of the Antarctic circumpolar current to recent climate change. Nature Geoscience, $\mathbf{1}$ $864-869$

Bopp L, Resplandy L, Orr JC et al. (2013) Multiple stressors of ocean ecosystems in the 21st century: projections with CMIP5 models. Biogeosciences Discussions, 10, 6225-6245.

Boyd PW (2011) Beyond ocean acidification. Nature Geoscience, 4, 273-274.

Boyd PW, Ellwood MJ (2010) The biogeochemical cycle of iron in the ocean. Nature Geoscience, 3, 675-682.

Boyd PW, Doney SC, Strzepek R, Dusenberry J, Lindsay K, Fung I (2008) Climatemediated changes to mixed-layer properties in the Southern Ocean: assessing the phytoplankton response. Biogeosciences, 5, 847-864.

Boyd PW, Arrigo KR, Strzepek R, Van Dijken GL (2012) Mapping phytoplankton iron utilization: insights into Southern Ocean supply mechanisms. Journal of Geophysical Research, 117, C06009.

Bracegirdle TJ, Connolley WM, Turner J (2008) Antarctic climate change over the twenty-first century. Journal of Geophysical Research, 113, D03103.

Bracegirdle TJ, Shuckburgh E, Sallée J-B et al. (2013) Assessment of surface winds over the Atlantic, Indian, and Pacific Ocean sectors of the Southern Ocean in CMIP5 models: historical bias, forcing response, and state dependence. Journal of Geophysical Research: Atmospheres, 118, 547-562.

Brandt A, Gutt J (2011) Biodiversity of a unique environment: the Southern Ocean benthos threat by climate change. In: Biodiversity Hotspots (eds Zachos F, Habel JC), pp. 503-526. Springer Publishers, Heidelberg.

Byrne M (2011) Impact of ocean warming and ocean acidification on marine invertebrate life history stages: vulnerabilities and potential for persistence in a changing ocean. Oceanography and Marine Biology, 49, 1-42.

Cai W, Shi G, Cowan T, Bi D, Ribbe J (2005) The response of the Southern Annular Mode, the East Australian Current, and the southern mid-latitude ocean circulation to global warming. Geophysical Research Letters, 32, L23706.

Chapman EW, Hofmann EE, Patterson DL, Ribic CA, Fraser WR (2011) Marine and terrestrial factors affecting Adélie penguin Pygoscelis adeliae chick growth and recruitment off the western Antarctic Peninsula. Marine Ecology Progress Series, 436, 273-289.

Charlson RJ, Lovelock JE, Andreae MO, Warren SG (1987) Oceanic phytoplankton, atmospheric sulphur, cloud albedo and climate. Nature, 326, 655-655.

Cheung WWL, Lam VWY, Pauly D (eds.) (2008) Modelling Present and Climate-Shifted Distributions of Marine Fisheries and Invertebrates. University of British Columbia, The Fisheries Centre, Vancouver.

Clark GF, Stark JS, Johnston EL, Runcie JW, Goldsworthy PM, Raymond B, Riddle MJ (2013) Light-driven tipping points in polar ecosystems. Global Change Biology, 19, 3749-3761.

Clarke A, Johnston NM (2003) Antarctic marine benthic diversity. Oceanography and Marine Biology: An Annual Review, 41, 47-114.

Clarke A, Murphy EJ, Meredith MP, King JC, Peck LS, Barnes DKA, Smith RC (2007) Climate change and the marine ecosystem of the western Antarctic Peninsula. Philosophical Transactions of the Royal Society B: Biological Sciences, 362, 149-166.

Collins MA, Rodhouse PGK (2006) Southern Ocean cephalopods. Advances in Marine Biology, 50, 191-265.

Collins MA, Brickle P, Brown J, Belchier M (2010) The Patagonian toothfish: biology, ecology and fishery. In: Advances in Marine Biology, vol. 58 (ed. Lesser M), pp. 227 300. Elsevier Academic Press Inc, San Diego.

Collins MA, Stowasser G, Fielding S et al. (2012) Latitudinal and bathymetric patterns in the distribution and abundance of mesopelagic fish in the Scotia Sea. Deep-Sea Research II, 59, 189-198.

Comiso J (1999) Bootstrap sea ice concentrations for NIMBUS-7 SMMR and DMSP SSM/ I-SSMIS. Version 2 (15 February 1997 to 14 February 2013), updated 2013. NASA DAAC at the National Snow and Ice Data Center, Boulder, CO, USA.

Comiso JC, Kwok R, Martin S, Gordon AL (2011) Variability and trends in sea ice extent and ice production in the Ross Sea. Journal of Geophysical Research, 116, C04021.

Constable A, Doust S (2009) Southern Ocean Sentinel - an international program to asses climate change impacts on marine ecosystems: report of an international workshop, Hobart, April 2009, ACE CRC, Commonwealth of Australia \& WWF-Australia. 
Constable AJ, Nicol S, Strutton PG (2003) Southern Ocean productivity in relation to spatial and temporal variation in the physical environment. Journal of Geophysical Research, 108, 1-10.

Cook A, Vaughan D (2010) Overview of areal changes of the ice shelves on the Antarctic Peninsula over the past 50 years. Cryosphere, 4, 77-98.

Cook A, Fox A, Vaughan D, Ferrigno J (2005) Retreating glacier fronts on the Antarctic Peninsula over the past half century. Science, 308, 541-544

Costa DP (1993) The relationship between reproductive and foraging energetics and the evolution of the Pinnipedia. In: Marine Mammals: Advances in Behavioural and Population Biology (ed. Boyd IL), pp. 293-314. Symposium Zoological Society of London, Oxford University Press, Oxford, UK.

Costa DP (2008) A conceptual model of the variation in parental attendance in response to environmental fluctuation: foraging energetics of lactating sea lions and fur seals. Aquatic Conservation: Marine and Freshwater Ecosystems, 17, S44-S52.

Costa DP, Shaffer SA (2012) Seabirds and marine mammals. In: Metabolic Ecology: A Scaling Approach (eds Sibly RM, Brown JH, Brown AK), pp. 225-233. John Wiley \& Sons, Ltd, Chichester, UK.

Costa DP, Huckstadt L, Crocker D, McDonald B, Goebel M, Fedak M (2010) Approaches to studying climate change and its role on the habitat selection of Antarctic pinnipeds. Integrative and Comparative Biology, 50, 1018-1030.

Croxall JP, Trathan PN, Murphy EJ (2002) Environmental change and Antarctic seabird populations. Science, 297, 1510-1514

Cubillos JC, Wright SW, Nash G et al. (2007) Calcification morphotypes of the coccolithophorid Emiliania huxleyi in the Southern Ocean: changes in 2001-2006 compared to historical data. Marine Ecology-Progress Series, 348, 47-54.

Curran M, Van Ommen T, Morgan V, Phillips V, Palmer A (2003) Ice core evidence for Antarctic sea ice decline since the 1950s. Science, 302, 1203-1206.

Danovaro R, Corinaldesi C, Dell'anno A, Fuhrman JA, Middelburg JJ, Noble RT, Suttle CA (2011) Marine viruses and global climate change. FEMS Microbiology Reviews, 35, 993-1034.

Daw T, Adger W, Brown K, Badjeck M-C (2009) Climate change and capture fisheries: potential impacts, adaptation and mitigation. In: FAO Fisheries and Aquaculture Technical Paper No. 530 (eds Cochrane K, De Young D, Soto T, Bahri T), pp 107-150. FAO, Rome.

De Broyer C, Koubbi P (eds) (2014) SCAR Biogeographic Atlas of the Southern Ocean. Scientific Committee on Antarctic Research, Cambridge, UK.

Dierssen HM, Smith RC, Vernet M (2002) Glacial meltwater dynamics in coastal waters West of the Antarctic Peninsula. Proceedings of the National Academy of Sciences, 99, 1790-1795.

Dinniman MS, Klinck JM, Hofmann EE (2012) Sensitivity of circumpolar deep water transport and ice shelf basal melt along the West Antarctic Peninsula to changes in the winds. Journal of Climate, 25, 4799-4816.

Dong S, Sprintall J, Gille ST, Talley L (2008) Southern Ocean mixed-layer depth from Argo float profiles. Journal of Geophysical Research: Oceans, 113, C06013.

Dowdeswell JA, Bamber JL (2007) Keel depths of modern Antarctic icebergs and implications for sea-floor scouring in the geological record. Marine Geology, 243, 120-131

Drent RH, Daan S (1980) The prudent parent: energetic adjustements in avian breeding. Ardea, 68, 225-252.

Ducklow HW, Baker K, Martinson DG et al. (2007) Marine pelagic ecosystems: the West Antarctic Peninsula. Philosophical Transactions of the Royal Society B: Biological Sciences, 362, 67-94.

Ducklow H, Clarke A, Dickhut R et al. (2012a) The marine system of the western Antarctic Peninsula. In: Antarctic Ecosystems (eds Rogers A, Johnston N, Murphy E, Clarke A), pp. 121-159. Wiley-Blackwell, Chichester, UK

Ducklow HW, Schofield O, Vernet M, Stammerjohn S, Erickson M (2012b) Multiscale control of bacterial production by phytoplankton dynamics and sea ice along the western Antarctic Peninsula: a regional and decadal investigation. Journal of Marine Systems, 98-99, 26-39.

Duhamel G, Pruvost P, Bertignac M, Gasco N, Hautecoeur M (2011) Major fishery events in Kerguelen Islands: Notothenia rossi, Champsocephalus gunnari, Dissostichus eleginoides - Current distribution and status of stocks. In: The Kerguelen Plateau: Marine Ecosystem and Fisheries (eds Duhamel G, Welsford DC), pp. 275-286. Société française d'ichtyologie, Paris.

Durack PJ, Wijffels SE (2010) Fifty-year trends in global ocean salinities and their relationship to broad-scale warming. Journal of Climate, 23, 4342-4362.

Eastman JT, McCune AR (2000) Fishes on the Antarctic continental shelf: evolution of a marine species flock? Journal of Fish Biology, 57, 84-102.

Emmerson L, Southwell C (2008) Sea ice cover and its influence on Adélie penguin reproductive performance. Ecology, 89, 2096-2102.
Emmerson L, Pike R, Townsend A, Southwell C (2011) Variability in the breeding phenology of Adélie penguins: potential causes and consequences for reproductive success. Marine Ecology Progress Series, 440, 203-216.

Engel A, Schulz KG, Riebesell U, Bellerby R, Delille B, Schartau M (2008) Effects of $\mathrm{CO}_{2}$ on particle size distribution and phytoplankton abundance during a mesocosm bloom experiment (PeECE II). Biogeosciences, 5, 509-521.

Ericson JA, Ho MA, Miskelly A, King CK, Virtue P, Tilbrook B, Byrne M (2012) Combined effects of two ocean change stressors, warming and acidification, on fertilization and early development of the Antarctic echinoid Sterechinus neumayeri. Polar Biology, 35, 1027-1034.

Everson I, Goss C (1991) Krill fishing activity in the southwest Atlantic. Antarctic Science, 3, 351-358.

Fach BA, Hofmann EE, Murphy EJ (2006) Transport of Antarctic krill (Euphausia superba) across the Scotia Sea. Part II: krill growth and survival. Deep Sea Research Part I: Oceanographic Research Papers, 53, 1011-1043.

Farneti R, Delworth TL (2010) The role of mesoscale eddies in the remote oceanic response to altered Southern Hemisphere winds. Journal of Physical Oceanography, 40, 2348-2354.

Feldman GC, McClain CR (2013) MODISA Reprocessing 2013.0. In: Ocean Color Web. (eds Kuring N, Bailey SW). Accessed 1 February 2013 http:/ /oceancolor.gsfc.nasa. gov/, NASA Goddard Space Flight Center. http:/ /oceancolor.gsfc.nasa.gov/.

Feng Y, Hare C, Leblanc K et al. (2009) Effects of increased $p \mathrm{CO}_{2}$ and temperature on the North Atlantic spring bloom. I. The phytoplankton community and biogeochemical response. Marine Ecology-Progress Series, 388, 13-25.

Fitch DT, Moore JK (2007) Wind speed influence on phytoplankton bloom dynamics in the Southern Ocean marginal ice zone. Journal of Geophysical Research, 112, C08006

Flores H, Van Franeker JA, Siegel V et al. (2012) The association of Antarctic krill Euphausia superba with the under-ice habitat. PLOS ONE, 7, e31775.

Forcada J, Trathan PN (2009) Penguin responses to climate change in the Southern Ocean. Global Change Biology, 15, 1618-1630.

Forcada J, Trathan P, Reid K, Murphy E (2005) The effects of global climate variability in pup production of Antarctic fur seals. Ecology, 86, 2408-2417.

Forcada J, Trathan P, Reid K, Murphy E, Croxall J (2006) Contrasting population changes in sympatric penguin species in association with climate warming. Global Change Biology, 12, 411-423.

Forcada J, Trathan PN, Murphy EJ (2008) Life history buffering in Antarctic mammals and birds against changing patterns of climate and environmental variation. Global Change Biology, 14, 2473-2488.

Fraser W, Hofmann E (2003) A predator's perspective on causal links between climate change, physical forcing and ecosystem response. Marine Ecology-Progress Series, $265,1-15$.

Gerringa LJA, Alderkamp A-C, Laan P et al. (2012) Iron from melting glaciers fuels the phytoplankton blooms in Amundsen Sea (Southern Ocean): iron biogeochemistry. Deep Sea Research Part II: Topical Studies in Oceanography, 71-76, $16-31$

Gille S (2008) Decadal-scale temperature trends in the Southern Hemisphere Ocean. Journal of Climate, 21, 4749-4765.

Gillies CL, Stark JS, Johnstone GJ, Smith SDA (2012) Carbon flow and trophic structure of an Antarctic coastal benthic community as determined by $\delta 13 \mathrm{C}$ and $\delta 15 \mathrm{~N}$. Estuarine, Coastal and Shelf Science, 97, 44-57.

Gjøsaeter J, Kawaguchi K (1980) A review of the world resources of mesopelagic fish. FAO Fisheries Technical Paper No. 193, Rome, Food and Agriculture Organization of the United Nations.

Golden KM, Ackley SF, Lytle VI (1998) The percolation phase transition in sea ice. Science, 282, 2238-2241.

Grant S, Constable A, Raymond B, Doust S (2006) Bioregionalisation of the Southern Ocean: Report of Experts Workshop, WWF- Australia and ACE CRC. Hobart, September 2006

sen Gupta A, Santoso A, Taschetto AS, Ummenhofer CC, Trevena J, England MH (2009) Projected changes to the Southern Hemisphere ocean and sea ice in the IPCC AR4 Climate Models. Journal of Climate, 22, 3047-3078.

sen Gupta A, Arkhipkin I, McNeil B (2012) Variability and change in the ocean. In: The Future of the World's Climate (eds Henderson-Sellers A, McGuffie K), pp. 141165. Elsevier, Amsterdam.

Gutt J, Piepenburg D (2003) Scale-dependent impact on diversity of Antarctic benthos caused by grounding of icebergs. Marine Ecology Progress Series, 253, 77-83.

Gutt J, Gerdes D, Klages M (1992) Seasonality and spatial variability in the reproduction of two Antarctic holothurians (Echinodermata). Polar Biology, 11, 533-544. 
Gutt J, Barratt I, Domack E et al. (2011) Biodiversity change after climate-induced iceshelf collapse in the Antarctic. Deep Sea Research Part II: Topical Studies in Oceanography, 58, 74-83.

Gutt J, Cape M, Dimmler W et al. (2013) Shifts in Antarctic megabenthic structure after ice-shelf disintegration in the Larsen area east of the Antarctic Peninsula. Polar Biology, 36, 895-906.

Hanchet SM, Rickard GJ, Fenaughty JM, Dunn A, Williams MJH (2008) A hypothetical life cycle for Antarctic toothfish in the Ross Sea region. CCAMLR Science, 15, 35-53.

Hare CE, Leblanc K, Ditullio GR et al. (2007) Consequences of increased temperature and $\mathrm{CO}_{2}$ for phytoplankton community structure in the Bering Sea. Marine Ecology-Progress Series, 352, 9-16.

Hellmer HH, Huhn O, Gomis D, Timmermann R (2010) On the freshening of the northwestern Weddell Sea continental shelf. Ocean Science Discussions, 7 , 2013-2042.

Helm KP, Bindoff NL, Church JA (2010) Changes in the global hydrological-cycle inferred from ocean salinity. Geophysical Research Letters, 37, L18701.

Heywood RB, Whitaker TM (1984) The Antarctic marine flora. In: Antarctic Ecology (ed. Laws RM), pp. 373-419. Academic Press, London, UK.

Hill SL, Phillips T, Atkinson A (2013) Potential climate change effects on the habitat of Antarctic krill in the Weddell quadrant of the Southern Ocean. PLOS ONE, 8, e72246.

Hindell MA, Bradshaw CJA, Harcourt R, Guinet C (2003) Ecosystem monitoring: are seals a potential tool for monitoring change in marine systems? In: Marine mammals. Fisheries, Tourism and Management Issues (eds Gales NJ, Hindell MA Kirkwood R), pp. 330-343. CSIRO Publishing, Melbourne.

Hindell M, Bradshaw C, Brook B, Fordham D, Hull C, McMahon C (2012) Long-term breeding phenology shift in royal penguins. Ecology and Evolution, 2, 1563-1571.

Hoffmann LJ, Breitbarth E, Boyd PW, Hunter KA (2012) Influence of ocean warming and acidification on trace metal biogeochemistry. Marine Ecology Progress Series, 470, 191-205.

Hofmann GE, Barry JP, Edmunds PJ, Gates RD, Hutchins DA, Klinger T, Sewell MA (2010) The effect of ocean acidification on calcifying organisms in marine ecosystems: an organism-to-ecosystem perspective. Annual Review of Ecology, Evolution, and Systematics, 41, 127-147.

Hogg AM, Meredith MP, Blundell JR, Wilson C (2008) Eddy heat flux in the Southern Ocean: response to variable wind forcing. Journal of Climate, 21, 608-620.

Holland PR, Kwok R (2012) Wind-driven trends in Antarctic sea-ice drift. Nature Geoscience, 5, 872-875.

Hollowed AB, Planque B, Loeng H (2013) Potential movement of fish and shellfish stocks from the Sub-Arctic to the Arctic Ocean. Fisheries Oceanography, 22, 355-370.

Hosie GW, Mormede S, Raymond B, Takahashi K, Kitchener J (2014) Mesozooplankton communities. In: SCAR Biogeographic Atlas of the Southern Ocean (eds De Broyer C, Koubbi P), pp. 1-10. Scientific Committee on Antarctic Research, Cambridge, UK.

Hulley PA (1981) Results of the research cruises of FRV 'Walther Herwig' to South America. 58. Family Myctophidae (Osteichthyes, Myctophiformes). Arch Fischereiwiss, 31 (Suppl. 1): 1-303.

Hunt B, Hosie G (2005) Zonal structure of zooplankton communities in the Southern Ocean South of Australia: results from a $2150 \mathrm{~km}$ continuous plankton recorder transect. Deep-Sea Research I, 52, 1241-1271.

Hunt B, Hosie G (2006a) The seasonal succession of zooplankton in the Southern Ocean south of Australia, part I: the seasonal ice zone. Deep Sea Research I, 53, 1182-1202

Hunt B, Hosie G (2006b) The seasonal succession of zooplankton in the Southern Ocean south of Australia, part II: the sub-antarctic to Polar Frontal Zones. Deep Sea Research I, 53, 1203-1223.

Inchausti P, Guinet C, Koudil M et al. (2003) Inter-annual variability in the breeding performance of seabirds in relation to oceanographic anomalies that affect the Crozet and the Kerguelen sectors of the Southern Ocean. Journal of Avian Biology, 34, 170-176.

Ingels J, Vanreusel A, Brandt A et al. (2012) Possible effects of global environmental changes on Antarctic benthos: a synthesis across five major taxa. Ecology and Evolution, 2, 453-485.

Jacobs SS, Giulivi CF (2010) Large multidecadal salinity trends near the Pacific-Antarctic continental margin. Journal of Climate, 23, 4508-4524.

Jarman S, Elliott N, Nicol S, McMinn A, Newman S (1999) The base composition of the krill genome and its potential susceptibility to damage by UV-B. Antarctic Science, 11, 23-26.

Jarvis T, Kelly N, Kawaguchi S, Van Wijk E, Nicol S (2010) Acoustic characterisation of the broad-scale distribution and abundance of Antarctic krill (Euphausia superba) off East Antarctica (30-80 degrees E) in January-March 2006. Deep-Sea Research II, $57,916-933$.
Jenouvrier S, Barbraud C, Weimerskirch H (2003) Effects of climate variability on the temporal population dynamics of southern fulmars. Journal of Animal Ecology, 72, 576-587.

Jenouvrier S, Barbraud C, Weimerskirch H (2005a) Long-term contrasted responses to climate of two Antarctic seabird species. Ecology, 86, 2889-2903.

Jenouvrier S, Weimerskirch H, Barbraud C, Park Y, Cazelles B (2005b) Evidence of a shift in the cyclicity of Antarctic seabird dynamics linked to climate. Proceedings of the Royal Society B: Biological Sciences, 272, 887-895.

Jenouvrier S, Barbraud C, Weimerskirch H (2006) Sea ice affects the population dynamics of Adelie penguins in Terre Adelie. Polar Biology, 29, 413-423.

Jenouvrier S, Caswell H, Barbraud C, Holland M, Stroeve J, Weimerskirch H (2009) Demographic models and IPCC climate projections predict the decline of an emperor penguin population. Proceedings of the National Academy of Sciences of the United States of America, 106, 1844-1847.

Kaiser S, Barnes DKA, Sands CI, Brandt A (2009) Biodiversity of the Amundsen Sea (Southern Ocean): spatial patterns of richness and abundance in shelf isopods. Marine Biodiversity, 39, 27-43.

Kaiser S, Brandão S, Brix S et al. (2013) Patterns, processes and vulnerability of Southern Ocean benthos: a decadal leap in knowledge and understanding. Marine Biology, 160, 2295-2317.

Kasamatsu N, Hirano T, Kudoh S, Odate T, Fukuchi M (2004a) Dimethylsulfoniopropionate production by psychrophilic diatom isolates. Journal of Phycology, 40, 874-878.

Kasamatsu N, Kawaguchi S, Watanabe S, Odate T, Fukuchi M (2004b) Possible impacts of zooplankton grazing on dimethylsulfide production in the Antarctic Ocean. Canadian Journal of Fisheries and Aquatic Sciences, 61, 736-743.

Kato A, Ropert-Coudert Y (2006) Rapid increase in Adelie penguin populations in the Lutzow-Holm Bay area since the mid 1990s. Polar Bioscience, 20, 55-62.

Kawaguchi S, Satake M (1994) Relationship between recruitment of the Antarctic kril and the degree of ice cover near the South Shetland Islands. Fisheries Science, 60 123-124.

Kawaguchi S, Nicol S, Taki K, Naganobu M (2006) Fishing ground selection in the Antarctic krill fishery: trends in patterns across years, seasons and nations. CCAMLR Science, 13, 117-141.

Kawaguchi S, Yoshida T, Finley LA, Cramp P, Nicol S (2007) The krill maturity cycle: a conceptual model of the seasonal cycle in Antarctic krill. Polar Biology, 30, 689-698.

Kawaguchi S, Nicol S, Press AJ (2009) Direct effects of climate change on the Antarctic krill fishery. Fisheries Management and Ecology, 16, 424-427.

Kawaguchi S, Kurihara H, King R et al. (2011) Will krill fare well under Southern Ocean acidification? Biology Letters, 7, 288-291.

Kawaguchi S, Ishida A, King R et al. (2013) Risk maps for Antarctic krill under projected Southern Ocean acidification, Nature Climate Change, 3, 843-847.

Kerry KR, Riddle M (eds.) (2009) Health of Antarctic Wildlife: A Challenge for Science and Policy. Springer, NY.

Kirchman DL, Anxelu X, Moran G, Ducklow H (2009) Microbial growth in the polar oceans - role of temperature and potential impact of climate change. Nature Reviews Microbiology, 7, 451-459.

Kock K-H (1992) Antarctic Fish and Fisheries. Cambridge University Press, Cambridge.

Kock K-H, Everson I (1997) Biology and ecology of mackerel icefish, Champsocephalus gunnari: an Antarctic fish lacking hemoglobin. Comparative Biochemistry and Physiology Part A: Physiology, 118, 1067-1077.

Krüger O, Graßl H (2011) Southern Ocean phytoplankton increases cloud albedo and reduces precipitation. Geophysical Research Letters, 38, 8809-8809.

Kwok R, Comiso JC (2002) Southern Ocean climate and sea ice anomalies associated with the Southern Oscillation. Journal of Climate, 15, 487-501.

Lannuzel D, Schoemann V, De Jong J, Tison JL, Chou L (2007) Distribution and biogeochemical behaviour of iron in the East Antarctic sea ice. Marine Chemistry, 106, $18-32$

Larsen JB, Larsen A, Thyrhaug R, Bratbak G, Sandaa R-A (2008) Response of marine viral populations to a nutrient induced phytoplankton bloom at different $\mathrm{pCO}_{2}$ levels. Biogeosciences, 5, 523-533.

Lea MA, Guinet C, Cherel Y, Duhamel G, Dubroca L, Pruvost P, Hindell M (2006) Impacts of climatic anomalies on provisioning strategies of a Southern Ocean predator. Marine Ecology Progress Series, 310, 77-94.

Lizotte MP (2001) The contributions of sea ice algae to Antarctic marine primary production. American Zoologist, 41, 57-73.

Lockyer C (2007) All creatures great and smaller: a study in cetacean life history energetics. Journal of the Marine Biological Association of the United Kingdom, 87, 1035-1045.

Loeb V, Siegel V, Holm-Hansen O, Hewitt R, Fraser W, Trivelpiece W, Trivelpiece S (1997) Effects of sea-ice extent and krill or salp dominance on the Antarctic food web. Nature, 387, 897-900. 
Lohrer AM, Cummings VJ, Thrush SF (2013) Altered sea ice thickness and permanence affects benthic ecosystem functioning in coastal Antarctica. Ecosystems, 16, 224-236

Lovenduski NS, Gruber N (2005) Impact of the Southern annular mode on Southern Ocean circulation and biology. Geophysical Research Letters, 32, 11603.

Lynch H, Naveen R, Trathan P, Fagan W (2012) Spatially integrated assessment reveals widespread changes in penguin populations on the Antarctic Peninsula. Ecology, 93, 1367-1377.

Mackey A, Atkinson A, Hill S, Ward P, Cunningham N, Johnston N, Murphy E (2012) Antarctic macrozooplankton of the southwest Atlantic sector and Bellingshausen Sea: baseline historical distributions (Discovery investigations, 1928-1935) related to temperature and food, with projections for subsequent ocean warming. Deep Sea Research II, 59-60, 130-146.

Maksym T, Stammerjohn SE, Ackley S, Massom R (2012) Antarctic sea ice - a polar opposite? Oceanography, 25, 140-151

Marchant H, Davidson A, Wright S (2001) Antarctic marine microorganisms and climate change: impacts and feedbacks. Ocean Polar Research, 23, 401-410.

de la Mare W (1997) Abrupt mid-twentieth-century decline in Antarctic sea-ice extent from whaling records. Nature, 389, 57-60.

de la Mare W (2009) Changes in Antarctic sea-ice extent from direct historical observations and whaling records. Climate Change, 92, 461-493.

Massom RA, Stammerjohn SE (2010) Antarctic sea ice change and variability - physical and ecological implications. Polar Science, 4, 149-186.

Massom RA, Hill K, Barbraud C, Adams N, Ancel A, Emmerson E, Pook MJ (2009) Fast ice distribution in Adélie Land, East Antarctica: interannual variability and implications for emperor penguins Aptenodytes forsteri. Marine Ecology Progress Series, 374, 243-257.

Massom R, Reid P, Stammerjohn S, Raymond B, Fraser A, Ushio S (2013) Change and variability in East Antarctic sea ice seasonality, 1979/80-2009/10. PLoS ONE, 8, e64756.

McClintock JB, Angus RA, McDonald MR, Amsler CD, Catledge SA, Vohra YK (2009) Rapid dissolution of shells of weakly calcified Antarctic benthic macroorganisms indicates high vulnerability to ocean acidification. Antarctic Science, 21, 449-456.

McIntyre T, Ansorge IJ, Bornemann H, Plötz J, Tosh CA, Bester MN (2011) Elephant seal dive behaviour is influenced by ocean temperature: implications for climate change impacts on an ocean predator. Marine Ecology Progress Series, 441, 257-272.

McLeod DJ, Hallegraeff GM, Hosie GW, Richardson AJ (2012) Climate-driven range expansion of the red-tide dinoflagellate Noctiluca scintillans into the Southern Ocean. Journal of Plankton Research, 34, 332-337.

McMahon CR, Bester MN, Hindell MA, Brook BW, Bradshaw CJA (2009) Shifting trends: detecting environmentally mediated regulation in long-lived marine vertebrates using time-series data. Oecologia, 159, 69-82.

McNeil BI, Matear RJ (2008) Southern Ocean acidification: a tipping point at 450-ppm atmospheric $\mathrm{CO}_{2}$. Proceedings of the National Academy of Sciences, 105, 18860-18864.

Meijers AJS, Bindoff NL, Rintoul SR (2011a) Estimating the four-dimensional structure of the Southern Ocean using satellite altimetry. Journal of Atmospheric and Oceanic Technology, 28, 548-568.

Meijers AJS, Bindoff NL, Rintoul SR (2011b) Frontal movements and property fluxes: contributions to heat and freshwater trends in the Southern Ocean. Journal of Geophysical Research, 116, 8024-8024.

Meijers AJS, Shuckburgh E, Bruneau N, Sallée J-B, Bracegirdle TJ, Wang Z (2012) Representation of the Antarctic Circumpolar Current in the CMIP5 climate models and future changes under warming scenarios. Journal of Geophysical ResearchOceans, 117, C12008

Meiners KM, Vancoppenolle M, Thanassekos S et al. (2012) Chlorophyll $a$ in Antarctic sea ice from historical ice core data. Geophysical Research Letters, 39, L21602.

Melbourne-Thomas J, Wotherspoon S, Corney S, Molina-Balari E, Marini O, Constable A (2013) Optimal control and system limitation in a Southern Ocean ecosystem model. Deep-Sea Research II. doi: 10.1016/j.dsr2.2013.02.017.

Meredith M, Hogg A (2006) Circumpolar response of Southern Ocean eddy activity to a change in the Southern Annular Mode. Geophysical Research Letters, 33, L16608.

Meredith MP, King JC (2005) Rapid climate change in the ocean west of the Antarctic Peninsula during the second half of the 20th century. Geophysical Research Letters, 32, L19604.

Meredith MP, Gordon AL, Naveira Garabato AC, Abrahamsen EP, Huber BA, Jullion L, Venables HJ (2011) Synchronous intensification and warming of Antarctic Bottom Water outflow from the Weddell Gyre. Geophysical Research Letters, 38, L03603.

Meredith MP, Naveira Garabato AC, Hogg AM, Farneti R (2012) Sensitivity of the overturning circulation in the Southern Ocean to decadal changes in wind forcing. Journal of Climate, 25, 99-110.
Meskhidze N, Nenes A (2006) Phytoplankton and cloudiness in the Southern. Ocean Science, 314, 1419-1423.

Meyer B (2012) The overwintering of Antarctic krill, Euphausia superba, from an ecophysiological perspective. Polar Biology, 35, 15-37.

Midorikawa T, Inoue HY, Ishii M et al. (2012) Decreasing pH trend estimated from 35-year time series of carbonate parameters in the Pacific sector of the Southern Ocean in summer. Deep Sea Research I, 61, 131-139.

Moline MA, Claustre H, Frazer TK, Schofield O, Vernet M (2004) Alteration of the food web along the Antarctic Peninsula in response to a regional warming trend. Global Change Biology, 10, 1973-1980.

Montes-Hugo M, Doney SC, Ducklow HW, Fraser W, Martinson D, Stammerjohn SE Schofield O (2009) Recent changes in phytoplankton communities associated with rapid regional climate change along the western Antarctic Peninsula. Science, 323, 1470-1473.

Morrison AK, Hogg AM (2012) On the relationship between Southern Ocean overturning and ACC transport. Journal of Physical Oceanography, 43, 140-148.

Moy AD, Howard WR, Bray SG, Trull TW (2009) Reduced calcification in modern Southern Ocean planktonic foraminifera. Nature Geoscience, 2, 276-280.

Müller R, Bartsch I, Laepple T, Wiencke C (2011) Impact of oceanic warming on the distribution of seaweeds in polar and cold-temperate waters. In: Biology of Polar Benthic Algae (ed Wienke C), pp. 237-270. De Gruyter, Berlin, Germany.

Murphy EJ (1995) Spatial structure of the Southern Ocean ecosystems: predatorprey linkages in Southern Ocean food webs. Journal of Animal Ecology, 64, 333-347.

Murphy EJ, Hofmann EE (2012) End-to-end in Southern Ocean ecosystems. Current Opinion in Environmental Sustainability, 4, 264-271.

Murphy EJ, Thorpe SE, Watkins JL, Hewitt R (2004) Modeling the krill transport pathways in the Scotia Sea: spatial and environmental connections generating the seasonal distribution of krill. Deep Sea Research II, 51, 1435-1456.

Murphy E, Watkins J, Trathan P et al. (2007a) Spatial and temporal operation of the Scotia Sea ecosystem: a review of large-scale links in a krill centred food web. Philosophical Transactions of the Royal Society B-Biological Sciences, 362, $113-148$

Murphy EJ, Trathan PN, Jon LW et al. (2007b) Climatically driven fluctuations in Southern Ocean ecosystems. Proceedings of the Royal Society B: Biological Sciences, 274, 3057-3067.

Murphy EJ, Cavanagh RD, Hofmann EE et al. (2012a) Developing integrated models of Southern Ocean food webs: including ecological complexity, accounting for uncertainty and the importance of scale. Progress in Oceanography, 102, 74-92.

Murphy EJ, Watkins JL, Trathan PN et al. (2012b) Spatial and temporal operation of the scotia sea ecosystem. In: Antarctic Ecosystems (eds Rogers A, Johnston N, Murphy E, Clarke A), pp. 160-212. Wiley-Blackwell, Chichester, UK.

Murphy EJ, Hofmann EE, Watkins JL et al. (2013) Comparison of the structure and function of Southern Ocean regional ecosystems: the Antarctic Peninsula and South Georgia. Journal of Marine Systems, 109, 22-42.

Naganobu M, Kutsuwada K, Sasaki Y, Taguchi S, Siegel V (1999) Relationships between Antarctic krill (Euphausia superba) variability and westerly fluctuation and ozone depletion in the Antarctic Peninsula area. Journal of Geophysical Research, 104, 20651-20665.

Near TJ, Dornburg A, Kuhn KL et al. (2012) Ancient climate change, antifreeze, and the evolutionary diversification of Antarctic fishes. Proceedings of the National Academy of Sciences of the United States of America, 109, 3434-3439.

Nevoux M, Weimerskirch H, Barbraud C (2010) Long- and short-term influence of environment on recruitment in a species with highly delayed maturity. Oecologia, 162, 383-392.

Newman SI, Dunlap WC, Nicol S, Ritz D (2000) Antarctic krill (Euphausia superba) acquire a UV-asorbing mycosporine-like amino acid from dietary algae. Journal of Experimental Marine Biology and Ecology, 255, 93-110.

Newman SJ, Ritz D, Nicol S (2003) Behavioural reactions of Antarctic krll (Euphausia superba Dana) to ultraviolet and photosynthetically active radiation. Journal of Experimental Marine Biology and Ecology, 297, 203-217.

Nicol S (2006) Krill, currents, and sea ice: Euphausia superba and its changing environment. BioScience, 56, 111-120.

Nicol S, Brierley A (2010) Through a glass less darkly—new approaches for studying the distribution, abundance and biology of euphausiids. Deep-Sea Research II, 57, 496-507.

Nicol S, Endo Y (1997) Krill Fisheries of the World. UN FAO, Rome.

Nicol S, Raymond B (2012) Pelagic ecosystems in the waters off East Antarctica $\left(30^{\circ} \mathrm{E}-150^{\circ} \mathrm{E}\right)$. In: Antarctic Ecosystems: An Extreme Environment in a Changing World (eds Rogers A, Johnston N, Murphy E, Clarke A), pp. 243-254. Wiley-Blackwell, Chichester, UK. 
Nicol S, Worby A, Leaper R (2008) Changes in the Antarctic sea ice ecosystem: potential effects on krill and baleen whales. Marine and Freshwater Research, 59, 361-382.

Nicol S, Foster J, Kawaguchi S (2012) The fishery for Antarctic krill - recent developments. Fish and Fisheries, 13, 30-40.

O'Brien P, Post AL, Romeyn R (2009) Antarctic-wide geomorphology as an aid to habitat mapping and locating Vulnerable Marine Ecosystems. CCAMLR Workshop on Vulnerable Marine Ecosystems, Paper WS-VME-09/10. CCAMLR, La Jolla, California, USA

Orr JC, Fabry VJ, Aumont O et al. (2005) Anthropogenic ocean acidification over the twenty-first century and its impact on calcifying organisms. Nature, 437, 681-686.

Pakhomov EA, Froneman PW, Perissinotto R (2002) Salp/krill interactions in the Southern Ocean: spatial segregation and implications for the carbon flux. Deep Sea Research II, 49, 1881-1907.

Pearse JS, McClintock JB, Bosch I (1991) Reproduction of Antarctic benthic marine invertebrates: tempos, modes and timing. American Zoologist, 31, 65-80.

Peck LS (2005) Prospects for survival in the Southern Ocean: vulnerability of benthic species to temperature change. Antarctic Science, 17, 497-507.

Peck LS, Webb KE, Bailey DM (2004) Extreme sensitivity of biological function to temperature in Antarctic marine species. Functional Ecology, 18, 625-630.

Peck LS, Barnes DKA, Cook AJ, Fleming AH, Clarke A (2010) Negative feedback in the cold: ice retreat produces new carbon sinks in Antarctica. Global Change Biology, 16, 2614-2623.

Péron C, Authier M, Barbraud C, Delord K, Besson D, Weimerskirch H (2010) Interdecadal changes in at-sea distribution and abundance of subantarctic seabirds along a latitudinal gradient in the Southern Indian Ocean. Global Change Biology, 16, 1895-1909

Péron C, Weimerskirch H, Bost CA (2012) Projected poleward shift of king penguins (Aptenodytes patagonicus) foraging range at the Crozet Islands, southern Indian Ocean. Proceedings of the Royal Society B, 279, 2515-2523.

Pinkerton M, Smith AN, Raymond B, Hosie GW, Sharp B, Leathwick JR, BradfordGrieve JM (2010) Spatial and seasonal distribution of adult Oithona similis in the Southern Ocean: predictions using boosted regression trees. Deep-Sea Research II $57,469-485$.

Piñones A, Hofmann EE, Dinniman MS, Klinck JM (2011) Lagrangian simulation of transport pathways and residence times along the western Antactic Peninsula. Deep-Sea Research II, 58, 1524-1539.

Quartino ML, Klöser H, Schloss IR, Wiencke C (2001) Biomass and associations of benthic marine macroalgae from the inner Potter Cove (King George Island, Antarctica) related to depth and substrate. Polar Biology, 24, 349-355

Quetin LB, Ross RM, Fritsen CH, Vernet M (2007) Ecological responses of Antarctic krill to environmental variability: can we predict the future? Antarctic Science, 19, 253-266.

Quinn PK, Bates TS (2011) The case against climate regulation via oceanic phytoplankton sulphur emissions. Nature, 480, 51-56.

Raymond B, Meiners K, Fowler CW, Pasquer B, Williams GD, Nicol S (2009) Cumulative solar irradiance and potential large-scale sea ice algae distribution off East Antarctica $\left(30^{\circ} \mathrm{E}-150^{\circ} \mathrm{E}\right)$. Polar Biology, 32, 443-452.

Reynolds RW, Smith TM, Liu C, Chelton DB, Casey KS, Schlax MG (2007) Daily highresolution blended analyses for sea surface temperature. Journal of Climate, 20, 5473-5496.

Rintoul SR (1998) On the origin and influence of Adélie Land Bottom Water. In: Ocean, Ice and Atmosphere: Interactions at the Antarctic Continental Margin (eds Jacobs S, Weiss R), pp. 151-171. AGU, Washington DC.

Rintoul SR (2007) Rapid freshening of Antarctic Bottom Water formed in the Indian and Pacific oceans. Geophysical Research Letters, 34, L06606.

Rivalan P, Barbraud C, Inchausti P, Weimerskirch H (2010) Combined impacts of longline fisheries and climate on the persistence of the Amsterdam Albatross Diomedia amsterdamensis. Ibis, 152, 6-18.

Roberts D, Howard WR, Moy AD, Roberts JL, Trull TW, Bray SG, Hopcroft RR (2011a) Interannual pteropod variability in sediment traps deployed above and below the aragonite saturation horizon in the Sub-Antarctic Southern Ocean. Polar Biology, 34, 1739-1750.

Roberts J, Xavier JC, Agnew DJ (2011b) The diet of toothfish species Dissostichus eleginoides and Dissostichus mawsoni with overlapping distributions. Journal of Fish Biology, 79, 138-154.

Rodhouse PGK (2012) Role of squid in the Southern Ocean pelagic ecosystem and the possible consequences of climate change. Deep Sea Research II, 95, 129-138.

Rolland V, Weimerskirch H, Barbraud C (2010) Relative influence of fisheries and climate on the demography of four albatross species. Global Change Biology, 16, 1910-1922.
Rose JM, Caron DA (2007) Does low temperature constrain the growth rates of heterotrophic protists? Evidence and implications for algal blooms in cold waters. Limnology and Oceanography, 52, 886-895.

Russell JL, Stouffer RJ, Dixon KW (2006) Intercomparison of the Southern Ocean circulation in IPCC Coupled Model Control Simulations (plus Corrigendum August 2007). Journal of Climate, 19, 4560-4575, incl. corrigendum 2007.

Sallée JB, Speer KG, Rintoul SR (2010) Zonally asymmetric response of the Southern Ocean mixed-layer depth to the Southern Annular Mode. Nature Geoscience, 3 273-279.

Sallée J-B, Shuckburgh E, Bruneau N, Meijers AJS, Bracegirdle TJ, Wang Z (2013a) Assessment of Southern Ocean mixed-layer depth in CMIP5 models: historical bias and forcing response. Journal of Geophysical Research-Oceans, 118, 1845-1862.

Sallée J-B, Shuckburgh E, Bruneau N, Meijers AJS, Bracegirdle TJ, Wang Z, Roy T (2013b) Assessment of Southern Ocean water mass circulation and characteristics in CMIP5 models: historical bias and forcing response. Journal of Geophysical Research-Oceans, 118, 1830-1844.

Scambos T, Hulbe M, Fahnestock (2003) Climate-induced ice shelf disintegration in the Antarctic Peninsula. In: Antarctic Peninsula Climate Variability: Historical and Paleoenvironmental Perspectives (eds Domack E, Burnett A, Bindschalder R, Convey P, Kirby M), pp. 79-92. AGU, Washington DC.

Schmidt K, Atkinson A, Steigenberger S et al. (2011) Seabed foraging by Antarctic krill: implications for stock assessment, bentho-pelagic coupling, and the vertical transfer of iron. Limnology and Oceanography, 56, 1411-1428.

Schwarz LK, Goebel ME, Costa DP, Kilpatrick AM (2013) Top-down and bottom-up influences on demographic rates of Antarctic fur seals Arctocephalus gazella. Journal of Animal Ecology, 82, 903-911.

Shi D, Xu Y, Hopkinson BM, Morel FMM (2010) Effect of ocean acidification on iron availability to marine phytoplankton. Science, 327, 676-679.

Siegel V, Loeb V (1995) Recruitment of Antarctic krill Euphausia superba and possible causes for its variability. Marine Ecology Progress Series, 123, 45-56.

Siniff DB, Garrott RA, Rotella JJ, Fraser WR, Ainley DG (2008) Opinion: projecting the effects of environmental change on Antarctic seals. Antarctic Science, 20, 425-435.

Smale DA, Barnes DK (2008) Likely responses of the Antarctic benthos to climaterelated changes in physical disturbance during the 21st century, based primarily on evidence from the West Antarctic Peninsula region. Ecography, 31, 289-305.

Smale DA, Brown KM, Barnes DKA, Fraser KPP, Clarke A (2008) Ice scour disturbance in Antarctic waters. Science, 321, 371

Smetacek V, Nicol S (2005) Polar ocean ecosystems in a changing world. Nature, 437 , 362-368.

Smith WO Jr, Comiso JC (2008) Influence of sea ice on primary production in the Southern Ocean: a satellite perspective. Journal of Geophysical Research, 113, C05S93.

Smith WO Jr, Nelson DM (1985) Phytoplankton bloom produced by a receding ice edge in the Ross Sea: spatial coherence with the density field. Science, 227, 163-166.

Smith WO Jr, Ainley DG, Cattaneo-Vietti R, Hofmann EE (2012) The Ross Sea continental shelf: regional biogeochemical cycles, trophic interactions, and potential future changes. In: Antarctic Ecosystems: An Extreme Environment In A Changing World (eds Rogers A, Johnston N, Murphy E, Clarke A), pp. 213-242. J. Wiley and Sons, London.

Sokolov S, Rintoul SR (2007) On the relationship between fronts of the Antarctic Circumpolar Current and surface chlorophyll concentrations in the Southern Ocean Journal of Geophysical Research, 112, C07030.

Sokolov S, Rintoul SR (2009) Circumpolar structure and distribution of the Antarctic Circumpolar Current fronts. 2: variability and relationship to sea surface height. Journal of Geophysical Research, 114, 1-15.

Sokolov S, Rintoul SR, Wienecke B (2006) Tracking the polar front south of New Zealand using penguin dive data. Deep-Sea Research II, 53, 591-607.

Stammerjohn SE, Massom R, Rind D, Martinson D (2012) Regions of rapid sea ice change: an inter-hemispheric seasonal comparison. Geophysical Research Letters, 39, L06501.

Strzepek RF, Maldonado MT, Hunter KA, Frew RD, Boyd PW (2011) Adaptive strategies by Southern Ocean phytoplankton to lessen iron limitation: uptake of organically complexed iron and reduced cellular iron requirements. Limnology and Oceanography, 56, 1983-2002.

Sura P, Gille ST (2010) Stochastic dynamics of sea surface height variability. Journal of Physical Oceanography, 40, 1582-1596.

Takahashi K, Kawaguchi S, Hosie G, Toda T, Naganobu M, Fukuchi M (2010) Surface zooplankton distribution in the Drake Passage recorded by Continuous Plankton Recorder (CPR) in the austral summer of 2000. Polar Science, 3, 235-245. 
Taylor MH, Losch M, Bracher A (2013) On the drivers of phytoplankton blooms in the Antarctic marginal ice zone: a modeling approach. Journal of Geophysical Research, 118, 63-75.

Thomas DN, Dieckmann GS (eds.) (2010) Sea Ice: An Introduction to Its Physics, Chemistry, Biology and Geology. Blackwell, Oxford UK.

Thompson DWJ, Solomon S, Kushner PJ, England MH, Grise KM, Karoly DJ (2011) Signatures of the Antarctic ozone hole in Southern Hemisphere surface climate change. Nature Geoscience, 4, 741-749.

Thorpe SE, Murphy EJ, Watkins JL (2007) Circumpolar connections between Antarctic krill (Euphausia superba Dana) populations: investigating the roles of ocean and sea ice transport. Deep Sea Research I, 54, 792-810.

Tison J-L, Worby A, Delille B et al. (2008) Temporal evolution of decaying summer first-year sea ice in the Western Weddell Sea, Antarctica. Deep Sea Research II, 55, 975-987

Tortell PD, Payne CD, Li Y et al. (2008) $\mathrm{CO}_{2}$ sensitivity of Southern Ocean phytoplankton. Geophysical Research Letters, 35, L04605.

Trathan P, Reid K (2009) Exploitation of the marine ecosystem in the sub-Antarctic: historical impacts and current consequences. Papers and Proceeding of the Royal Society of Tasmania, 143, 9-14.

Trathan P, Murphy E, Forcada J, Croxall J, Reid K, Thorpe S (2006) Physical forcing in the southwest Atlantic: ecosystem control. In: Top Predators in Marine Ecosystem (eds Boyd I, Wanless S, Camphuysen C), pp. 28-45. Cambridge University Press, Cambridge.

Trathan P, Forcada J, Murphy E (2007) Environmental forcing and Southern Ocean marine predator populations: effects of climate change and variability. Philosophical Transactions of the Royal Society B: Biological Sciences, 362, 2351-2365.

Trathan PN, Ratcliffe N, Masden EA (2012) Ecological drivers of change at South Georgia: the krill surplus, or climate variability. Ecography, 35, 1-12.

Trivelpiece W, Hinke J, Miller A, Reiss C, Trivelpiece S, Watters G (2011) Variability in krill biomass links harvesting and climate warming to penguin population changes in Antarctica. Proceedings of the National Academy of Sciences of the United States of America, 108, 7625-7628.

Tuck GN, Polacheck T, Croxall JP, Weimerskirch H (2001) Modelling the impact of fishery by-catches on albatross populations. Journal of Applied Ecology, 38, 1182-1196.

Turner J, Bindschadler R, Convey P et al. (eds.) (2009a) Antarctic Climate Change and the Environment: A Contribution to the International Polar Year 2007-2008. Scientific Committee on Antarctic Research (SCAR), Cambridge.

Turner J, Chenoli SN, Abu Samah A, Marshall G, Phillips T, Orr A (2009b) Strong wind events in the Antarctic. Journal of Geophysical Research, 114, 18103-18103.

Turner J, Comiso J, Marshall G et al. (2009c) Non-annular atmospheric circulation change induced by stratospheric ozone depletion and its role in the recent increase of Antarctic sea ice extent. Geophysical Research Letters, 36, L08502.

Turner J, Bracegirdle TJ, Phillips T, Marshall GJ, Hosking JS (2012) An initial assessment of Antarctic sea ice extent in the CMIP5 models. Journal of Climate, 26, $1473-1484$

Turner JA, Barrand NE, Bracegirdle TJ et al. (2013) Antarctic climate change and the environment: an update. Polar Record. doi: 10.1017/S0032247413000296, 1-23.
Vancoppenolle M, Meiners KM, Michel C et al. (2013) Role of sea ice in global biogeochemical cycles: emerging views and challenges. Quaternary Science Reviews, 79, 207-230.

Venables HJ, Clarke A, Meredith MP (2013) Wintertime controls on summer stratification and productivity at the western Antarctic Peninsula. Limnology and Oceanography, 58, 1035-1047.

Ward P, Meredith M, Whitehouse M, Rothery P (2008) The summertime plankton community at South Georgia (Southern Ocean): comparing the historical (1926/ 1927) and modern (post 1995) records. Progress in Oceanography, 78, 241-256.

Ward P, Atkinson A, Venables HJ et al. (2012) Food web structure and bioregions in the Scotia Sea: a seasonal synthesis. Deep-Sea Research II, 59, 253-266.

Weimerskirch H, Brothers N, Jouventin P (1997) Population dynamics of wandering albatross Diomedea exulans and Amsterdam albatross D-amsterdamensis in the Indian Ocean and their relationships with long-line fisheries: conservation implications. Biological Conservation, 79, 257-270.

Weimerskirch H, Inchausti P, Guinet C, Barbraud C (2003) Trends in bird and seal populations as indicators of a system shift in the Southern Ocean. Antarctic Science, 15, 249-256.

Weimerskirch H, Louzao M, De Grissac S, Delord K (2012) Changes in wind pattern alter albatross distribution and life-history traits. Science, 335, 211-214.

Welsford DC, Candy SG, Lamb TD, Nowara GB, Constable AJ, Williams R (2011) Habitat use by Patagonian toothfish (Dissostichus eleginoides Smitt 1898) on the Kerguelen Plateau around Heard Island and the McDonald Islands. In: The Kerguelen Plateau: Marine Ecosystem and Fisheries (eds Duhamel G, Welsford DC), pp. 125136. Société française d'ichtyologie, Paris.

Whitehouse MJ, Meredith MP, Rothery P, Atkinson A, Ward P, Korb RE (2008) Rapid warming of the ocean around South Georgia, Southern Ocean, during the 20th century: forcings, characteristics and implications for lower trophic levels. Deep Sea Research I, 55, 1218-1228.

Wiedenmann J, Cresswell K, Mangel M (2008) Temperature-dependent growth of Antarctic krill: predictions for a changing climate from a cohort model. Marine Ecology Progress Series, 358, 191-202.

Wiedenmann J, Cresswell KA, Mangel M (2009) Connecting recruitment of Antarctic krill and sea ice. Limnology and Oceanography, 54, 799-811.

Wiencke C (1996) Recent advances in the investigation of Antarctic macroalgae. Polar Biology, 16, 231-240.

Wiencke C (2010) Biology of Polar Benthic Algae. Walter de Gruyter, Berlin, Germany.

Xavier JC, Cherel Y (2009) Cephalopod Beak Guide for the Southern Ocean. British Antarctic Survey, Cambridge, UK.

Xavier J, Croxall J, Trathan P, Wood A (2003) Feeding strategies and diets of breeding grey-headed and wandering albatrosses at South Georgia. Marine Biology, 143, 221-232

Yamada N, Suzumura M (2010) Effects of Seawater acidification on Hydrolytic enzyme activities. Journal of Oceanography, 66, 233-241.

Zerbini A, Clapham P, Wade P (2010) Assessing plausible rates of population growth in humpback whales from life-history data. Marine Biology, 157, 1225-1236. 